\title{
Speleogenesis in a lens of metamorphosed limestone and ankerite: Ochtiná Aragonite Cave, Slovakia
}

\author{
Pavel Bella (D) ${ }^{1,2^{*}}$, Pavel Bosák (D) ${ }^{3}$, Petr Pruner (D) ${ }^{3}$, Helena Hercman (iD ${ }^{4}$, \\ Katarína Pukanská (DD ${ }^{5}$, Karol Bartoš (DD ${ }^{5}$, L'udovít Gaál ${ }^{1}$, Dagmar Haviarová (D) ${ }^{1}$, \\ Peter Tomčík (D) ${ }^{6}$, and Šimon Kdýr (DD ${ }^{3}$ \\ ${ }^{1}$ State Nature Conservancy of the Slovak Republic, Slovak Caves Administration, Hodžova 11, 03101 Liptovský Mikuláš, Slovakia \\ ${ }^{2}$ Department of Geography, Faculty of Education, Catholic University in Ružomberok, Hrabovská cesta 1, 03104 Ružomberok, Slovakia \\ ${ }^{3}$ Institute of Geology of the Czech Academy of Sciences, Rozvojová 269, 16500 Praha 6-Lysolaje, Czechia \\ ${ }^{4}$ Institute of Geological Sciences, Polish Academy of Sciences, ul. Twarda 51/55, 00818 Warszawa, Poland \\ ${ }^{5}$ Institute of Geodesy, Cartography and GIS, Technical University of Košice, Park Komenského 19, 04001 Košice, Slovakia \\ ${ }^{6}$ Department of Chemistry and Physics, Faculty of Education, Catholic University in Ružomberok, Hrabovská cesta 1, 031 04 Ružomberok, Slovakia
}

Abstract: $\quad$ The Ochtiná Aragonite Cave (Western Carpathians) represents a unique natural phenomenon. It originated under particular lithological and hydrogeological conditions of the Ochtiná Karst in which several isolated lenses of Paleozoic crystalline limestone, partly metasomatically altered to ankerite, are enclosed by phyllites. Meteoric water seepage through non-carbonate rocks dissolved limestone and caused the oxidation of ankerite to Fe oxyhydroxides. Carbon dioxide produced during ankerite oxidation enhanced limestone dissolution. The maze cave consists of parallel fault-controlled linear passages and chambers interconnected by transverse horizontal passages. Phreatic and epiphreatic solution morphologies resulted from slowly moving or standing water. These include flat ceilings (Laugdecken), facets, lateral notches, convection ceiling cupola-shaped depressions, and spongework-like hollows. Flat ceilings were developed in several altitude positions, each of them probably closely below the slightly oscillated water table. Primary phreatic cupola-shaped depressions, truncated by flat ceilings, represent relics of the oldest cavities (pre-Quaternary? to Early Pleistocene). Inward-sloping smooth facets were not developed only in passages with flat ceilings, but also in the passages and halls with a vaulted ceiling. The asymmetrical shape of cusped depressions above the facets were documented in detail by a high-resolution cave topography with terrestrial laser scanning and digital photogrammetry. Middle-Late Pleistocene accumulation phases, identified by magnetostratigraphy of cave sediments and U-series dating of speleothems, are associated with phreatic and later epiphreatic development. The deposition on the bottom bedrock began before $1.8 \mathrm{Ma}$. The Brunhes/Matuyama boundary $(0.773 \mathrm{Ma})$ and Jaramillo magnetozone (0.990-1.071 Ma) were recorded in the profile in the Oválna chodba Passage. Slow depositional rate $(\sim 0.09 \mathrm{~cm} / \mathrm{kyr})$ calculated from magnetostratigraphy resulted from slow water movement in confined conditions in marbles completely enclosed by phyllites and no direct relation to the surface. Only occasionally turbid water was loaded in extremely fine-grained infiltration material and autochthonous Fe oxyhydroxides. The depositional rate in Mn-rich layer was much slower $(\sim 0.03 \mathrm{~cm} / \mathrm{kyr}$ ). Additional U-series dating confirmed that old aragonite generations (with ages about 500-450 ka and 143-121 ka) were partly corroded by repeated floods during Late Pleistocene humid episodes. Aragonite younger than $13.5 \mathrm{ka}$ is not corroded.

Keywords: $\quad$ Cave morphology, LiDAR, magnetostratigraphy, ankerite, speleogenesis Received 20 June 2021; Revised 26 October 2021; Accepted 5 November 2021

Citation: Bella, P., Bosák, P., Pruner, P., Hercman, H., Pukanská, K., Bartoš, K., Gaál, L., Haviarová, D., Tomčík, P., Kdýr, Š., 2022. Speleogenesis in a lens of metamorphosed limestone and ankerite: Ochtiná Aragonite Cave, Slovakia. International Journal of Speleology, 51(1), 13-28. https://doi.org/10.5038/1827-806X.51.1.2397

\section{INTRODUCTION}

The Ochtiná Aragonite Cave ("Ochtinská aragonitová jaskyña" in Slovak, OAC) belongs to the UNESCO World Heritage List within the Property No. 725:
"Caves of Aggtelek Karst and Slovak Karst". OAC, along with other smaller cavities were discovered in the Kapusta Adit in 1954 during iron ore exploration. The cave opened to public in 1972, after an artificial tunnel was excavated between 1966 and 1967. 
The OAC is formed in the lens of limestone, part of which was metasomatically altered to ankerite, $\mathrm{Ca}\left(\mathrm{Fe}^{2+}, \mathrm{Mg}\right)\left(\mathrm{CO}_{3}\right)_{2}$. According to Droppa (1957), the cave originated by the limestone dissolution and chemical weathering of the ankerite by meteoric waters infiltrating along steep faults when cavities were completely flooded, and outflow conduits were blocked by flushed Fe oxyhydroxides. While Droppa (1957) suggested the OAC developed during the Holocene, Kubiny (1959) linked it genesis with Pleistocene glacial periods. Homza et al. (1970) concluded that cave spaces were formed by Tertiary and Quaternary ankerite weathering and flushing of Fe oxyhydroxides. Complicated OAC morphology with numerous irregular larger and smaller spherical cavities led Nicod (1976) and Choppy (1994) to advocated for hydrothermal origin. However, no diagnostic minerals were detected in OAC (Cílek et al., 1998; Bosák et al., 2002). Gaál (1996) and Hurai et al. (2002) noted that the hydrothermal processes occurred in a deeper part of limestone complex only during Early to Late Cretaceous.

Gaál and Ženiš (1986), as well as Gaál (1996) suggested that iron oxidation in ankerite by meteoric waters was responsible for origin of the OAC and that the morphology of cavities is controlled by the shape of original ankerite bodies within limestone lenses. Modern cave morphologies resulted from the later dissolution of limestone walls. Similarly, Ščuka et al. (1988), Rajman et al. (1990, 1993), as well as Bosák et al. (2002) considered that the limestone dissolution was enhanced by $\mathrm{CO}_{2}$ released from decomposition of siderite/ankerite. Siderite $\mathrm{Fe}\left(\mathrm{CO}_{3}\right)$ and pyrite $\left(\mathrm{FeS}_{2}\right)$ were found in the Hrádok Massif (e.g., Mišik, 1953; Bystrický \& Fusán, 1954), but not directly in the OAC.

Phreatic and epiphreatic solution morphologies (solution flat ceiling, inward-sloping smooth facets, cupola-shaped depressions, and others) originated in slowly moving or standing water (Bella, 1998, 2004; Bella et al., 2000; Bosák et al., 2002). Ford and Williams (2007) presented the OAC as an excellent example of "notch caves" originating from lateral corrosion along the standing water table in the lens of metamorphosed limestone enclosed by phyllites.

Complementary multidisciplinary research aiming at refining the origin and development of the OAC was conducted since 2013. New knowledge and data obtained from a high-resolution documentation of cave topography and morphology, high-resolution magnetostratigraphy of cave sediments, and additional U-series speleothem dating are presented here to explain the genesis of the OAC.

\section{LOCATION AND SETTINGS}

The OAC is located in the Ochtina Karst on the north-western slope of Hrádok Hill (809 m above sea level; asl) in the eastern part of Revúcka vrchovina Highland (Slovenské rudohorie Mountains, centralsouthern Slovakia; Fig. 1A, B). The artificial tunnel entrance to the OAC is at $642 \mathrm{~m}$ asl. The cave is about 300 m long (Ševčík \& Kantor, 1956) with a vertical relief of 33 m (Pukanská et al., 2020).

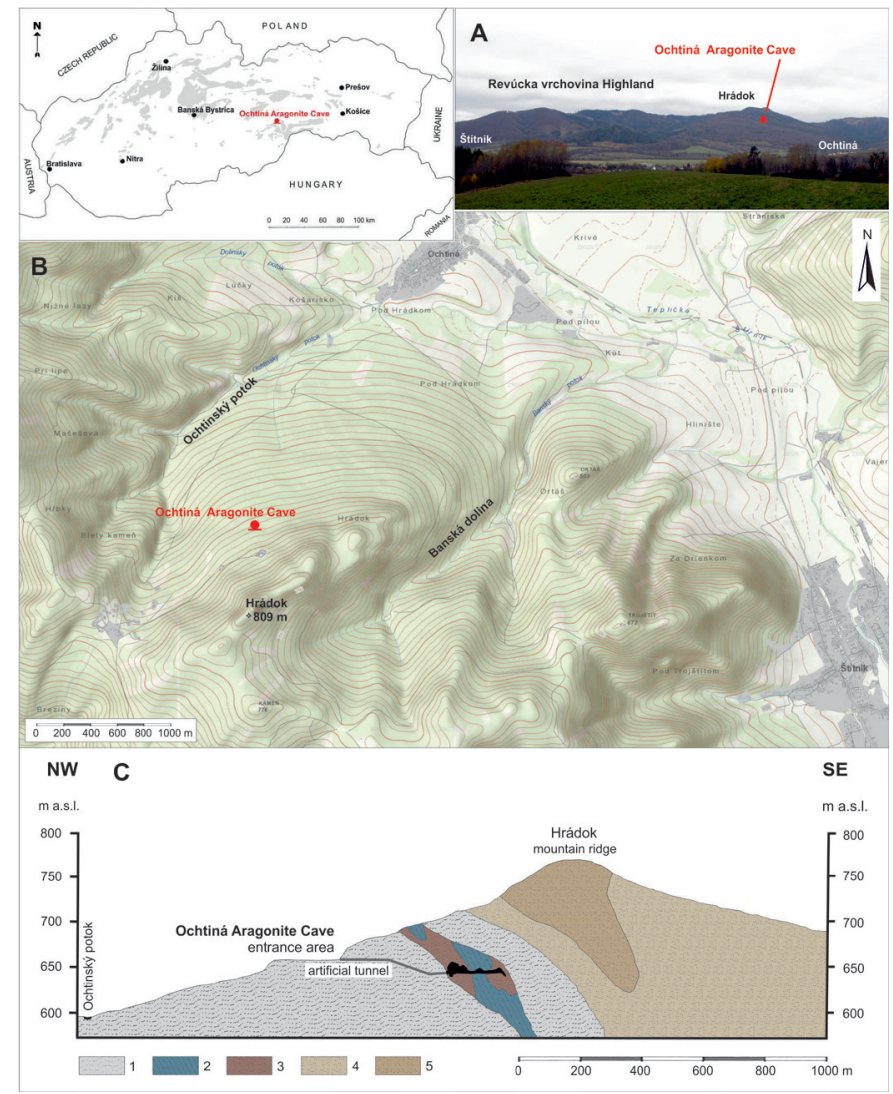

Fig. 1. Location of the Ochtiná Aragonite Cave and the geological settings of the Hrádok Massif. A) Hrádok Massif from the Štítnik River Valley (Photo by P. Bella); B) Map of the vicinity of the cave (topography: https://zbgis.skgeodesy.sk/mkzbgis/sk); C) Geological cross-section sketch (modified from Gaál, 2004). 1. Drnava Formation, graphitic and sericitic-graphitic phyllites, 2. Crystalline limestone (marbles), 3. Rožňava Formation (ankerite, weathered ankerite), 4. Metamorphosed quartz greywacke and sandstone, 5. Metamorphosed quartz conglomerate. 
The OAC is formed in Lower Devonian crystalline limestone (marble) and ankerite of the Drnava Formation (Lower Paleozoic; Gelnica Group/Gemeric Unit) at the contact zone of Veporic and Gemeric units. Three carbonate lenses in the Hrádok Hill are completely or almost surrounded by graphitic and sericitic-graphitic phyllites rich in sulfides in places (Bystrický \& Fusán, 1954; Bajaník et al., 1983; Gaál, 2004; Fig. 1C). They are $\sim 50 \mathrm{~m}$ in thickness with a total length of $800 \mathrm{~m}$ and general inclination of $40^{\circ}-45^{\circ}$ SE (Ševčik \& Kantor, 1956). The Drnava Formation is unconformably overlain by weakly metamorphosed quartz greywacke and sandstone, and quartz conglomerate of the Rožn̆ava Formation (Permian; Gočaltovo Group/Gemeric Unit). Conglomerates build the present highest part of the Hrádok Hill (e.g., Bystrický \& Fusán, 1954; Bajaník et al., 1983; Gaál, 2004; Grecula et al., 2009; Fig. 1C).

The Drnava Formation underwent low-pressure metamorphism in greenschist facies probably in Viséan-Namurian/Serpukhovian (Carboniferous) and folding/faulting at the end of the Variscan Orogeny (e.g., Fusán, 1957; Grecula, 1982; Sassi \& Vozárová, 1987; Vozárová \& Vozár, 1988). Hydrothermal fluids ascended along steep faults leaching Paleozoic metabasalts (Grecula, 1982) when Fe (Mn)-rich fluids concentrated their mineral load in limestone lenses. Because Ca was metasomatically depleted, a part of limestone was altered to ankerite (e.g., Mišik, 1953; Bystrický \& Fusán, 1954). Hurai et al. (2002) assumed crystallization of quartz-ankerite-sulfidic ores from basinal brines were expelled during Early to Middle Cretaceous compression at the closure of the Meliata Ocean. Only some Variscan faults were rejuvenated during the Alpine Orogeny and cleavage in marble originated (Gaál, 2004).

Nearly $56 \%$ of the OAC is developed in marble. Marble lenses are generally NE-SW-trending and strata dip is steeper in the southern part of the cave $\left(60^{\circ}-85^{\circ}\right)$ than in the northern one $\left(30^{\circ}-50^{\circ}\right)$. The ESE-WNW-trending Alpine cleavage oblique to Variscan faults is evident (Gaál, 2004). The ankerite is exposed on over $43 \%$ of cave walls, mostly along the NE-SW-trending faults that dip $70^{\circ}-80^{\circ} \mathrm{NW}$ (Gaál, 2004). They, as a part of the Hrádok fault zone (see Potočný et al., 2020), are associated with Alpine fault rejuvenation. Faults represent principal infiltration paths of meteoric waters into the cave.

Fe oxyhydroxides originated by ankerite oxidation and form several $\mathrm{cm}$-thick covers of ankerite bodies, mainly along faults. Fe oxyhydroxides have rusty- or light-brown color and consists of cryptocrystalline goethite, partly with increased $\mathrm{Mg}$ contents (e.g., Ševčik \& Kantor, 1956), and water content of $\sim 40 \%$ (Cílek et al., 1998; Bosák et al., 2002). Quartz veins up to $30 \mathrm{~cm}$ thick cut ankerite bodies and protrude from $\mathrm{Fe}$ oxyhydroxides on the weathered surface of ankerite (Ševčík \& Kantor, 1956).

Recent groundwater penetrates along bedding in marble lenses dipping in direction of north-eastern slope of the Hrádok Hill, where several springs in the Banská dolina Valley are situated $100 \mathrm{~m}$ lower than the OAC (Droppa, 1957). The north-western slope is drained by the Ochtinsky potok Brook. The OAC water likely reaches the surface in the spring at $613 \mathrm{~m}$ asl located north-east of the Kapusta Adit mouth (Ševčik \& Kantor, 1956; Droppa, 1957). Chemical composition of spring water is similar to cave groundwater (Rajman et al., 1990), i.e., mostly alkaline, moderately mineralized, with a temperature from 7.2 to $8.5^{\circ} \mathrm{C}$. In seepage as well as lake waters, the $\mathrm{Ca}-\mathrm{Mg}-\mathrm{HCO}_{3}^{-}$type is chemically dominant. Both are characterized by low sulfate concentrations up to 34-43 mg/L (Peško, 2002; Haviarová \& Peško, 2004; unpublished analyses from 2017 and 2018). The water table in cave lakes is $23 \mathrm{~m}$ higher than in the spring situated $480 \mathrm{~m}$ away.

\section{METHODOLOGY}

\section{Terrestrial laser scanning, digital photogrammetry, and geomorphological research}

The survey of the cave performed by terrestrial laser scanning (TLS) and digital close-range photogrammetry (DCRP) resulted in high-resolution topography and morphology of the OAC (for details see Pukanská et al., 2020). More than 121 million points from 54 survey stations were measured with a compact all-in-one full panoramic pulse laser scanner Leica ScanStation C10. The spatial resolution of 20 $\times 20 \mathrm{~mm}$ of the final point cloud was achieved. New cave map, sections, and the 3D model using these surveying technologies were created from the resulting point clouds, processed in computer-aided design software - Microstation V8i and Leica Cloudworks. We used a triangular mesh generation method by Poisson Surface Reconstruction algorithm (Bolitho et al., 2007) to create the 3D MESH model, where surfaces are represented as a polygonal mesh. Some specific morphologies (cusped depressions and below-lying smooth facets on the lower parts of cave walls) were mapped with the Structure-from-Motion (SfM) method of DCRP using digital camera DSLR Pentax K-5 with Pentax SMC DA $15 \mathrm{~mm}$ lens and processed in Agisoft PhotoScan Professional Edition software. TLS and SfM were performed and processed in the Institute of Geodesy, Cartography and GIS, Faculty of Mining, Ecology, Process Control and Geotechnologies of the Technical University in Košice, Slovakia.

Basic morphometric data on cave morphology and some selected specific solution morphologies (flat ceiling, facets) were generated. An inventory of solutional morphologies enabled to infer former speleogenetic processes (following the studies of Lange, 1962, 1963; Curl, 1966; Reinboth, 1971; Kempe et al., 1975).

\section{Paleomagnetic analysis}

Sediment profile in the eastern part of the Oválna chodba Passage (pilot samples distant 10-12 cm; Bosák et al., 2002) was revised (Fig. 2). High-resolution (for details see Bosák et al., 2003; Zupan Hajna et al., 2008) re-sampling of 40 samples in 2013 covered a $62-\mathrm{cm}$ thick profile with 2 to $4 \mathrm{~cm}$ resolution. Furthermore, 14 parallel samples (marked A, B) were 
taken at $4,10,17,24,31,41$, and $55 \mathrm{~cm}$ below the profile's top to control statistics of paleomagnetic parameters (Fig. 2B). Paleomagnetic analyses were performed and processed in the Department of Paleomagnetism, Institute of Geology of the Czech Academy of Sciences in Prưhonice by methodology described by Zupan Hajna et al. (2008) or Bella et al. (2019).

Sediments were sampled in non-magnetic plastic boxes oriented in situ. Unconsolidated samples were demagnetized by an alternating field up to $100 \mathrm{mT}$ in 13 steps on the LDA-3A apparatus (AGICO, Ltd.) or the Superconducting Rock Magnetometer (755 4K SRM). The isothermal remanent magnetization (IRM) and the saturation isothermal remanent magnetization (SIRM) were determined using the pulsed magnetometer MMPM, where the field takes values from 10 to $1,000 \mathrm{mT}$. The characteristic remanent magnetization (ChRM) of each sample was determined by subjecting its demagnetization results to the principal component analysis technique of Kirschvink (1980) and the computer program Remasoft 3 (Chadima \& Hrouda, 2006). The mean directions of the respective remanence components relative to the horizontal position of the rocks were calculated using the Fisher's (1953) statistics. The interpreted polarities of the geomagnetic field were correlated with normal and reverse magnetozones of the GPTS geomagnetic scale (Cande \& Kent, 1995), and calibrated using the ages of Cohen \& Gibbard (2019). The NRM magnitude and the interpretation of magnetic polarity record depend on the concentration and type of magnetic minerals in sediment.
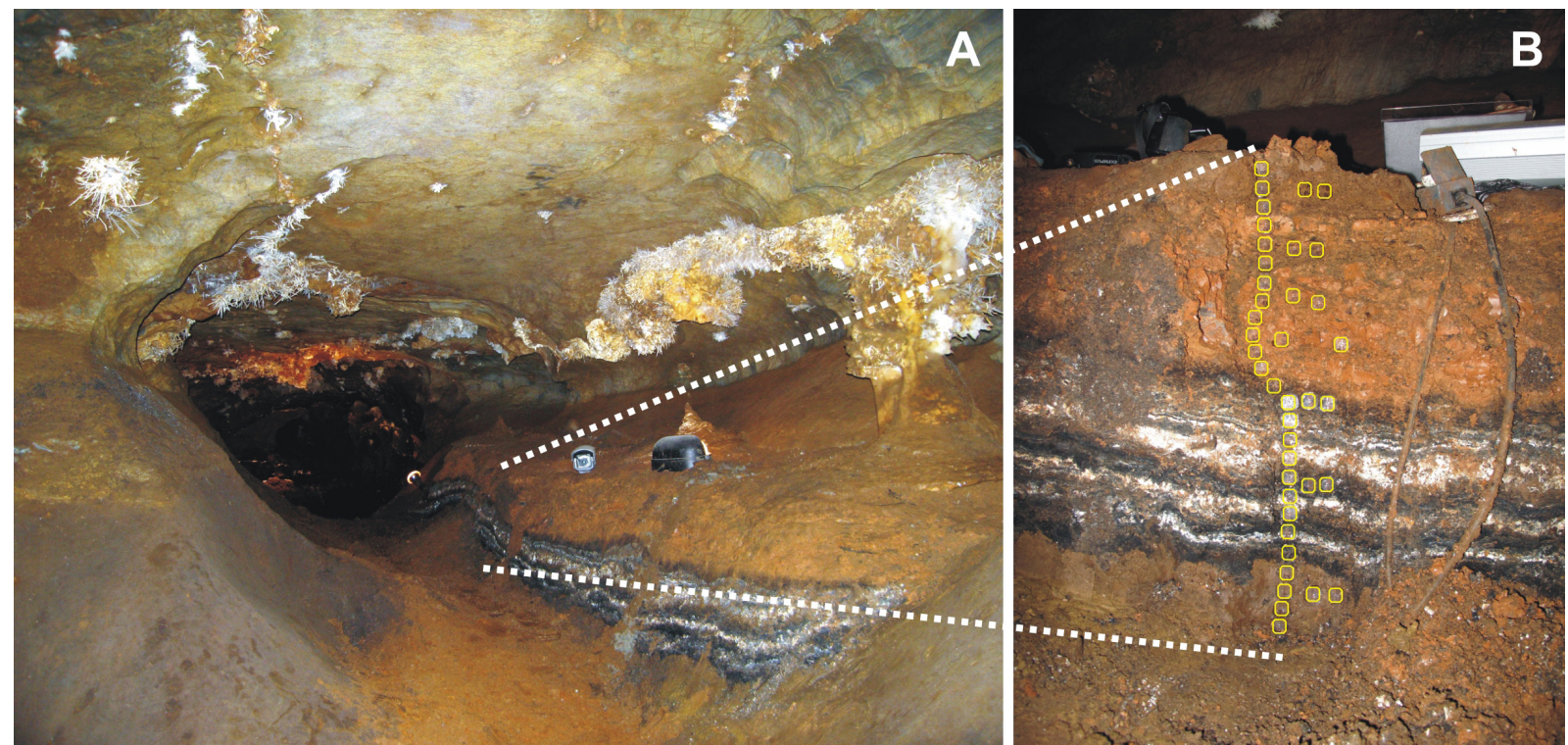

Fig. 2. Sedimentary profile in the Oválna chodba with paleomagnetic samples: A) general view; B) detail of sampling profile with paleomagnetic cubes (Photos by P. Bella).

\section{U-series dating}

Following the U-series dating of aragonite and calcite speleothems by D.C. Ford (in Rajman et al., 1990, 1993) and Bosák et al. (2002), two additional samples were collected to reconstruct development phases of the cave. Recrystallized flowstone preserved in the small ceiling cavity at the eastern edge of the Oválna chodba is truncated by a solution flat ceiling (OCH-4; $646.5 \mathrm{~m}$ asl; Figs. 4 and 5). The sample was taken to verify previous U-Th isotopic data and age of samples JOA 1 and JOA 2 (Bosák et al.; 2002). The second sample (OCH-5; $646.7 \mathrm{~m}$ asl) is from a kidneyshaped aragonite precipitated on the ceiling of the Hviezdna sieñ Hall (Figs. 4 and 5) whose surface was later corroded by floodwater.
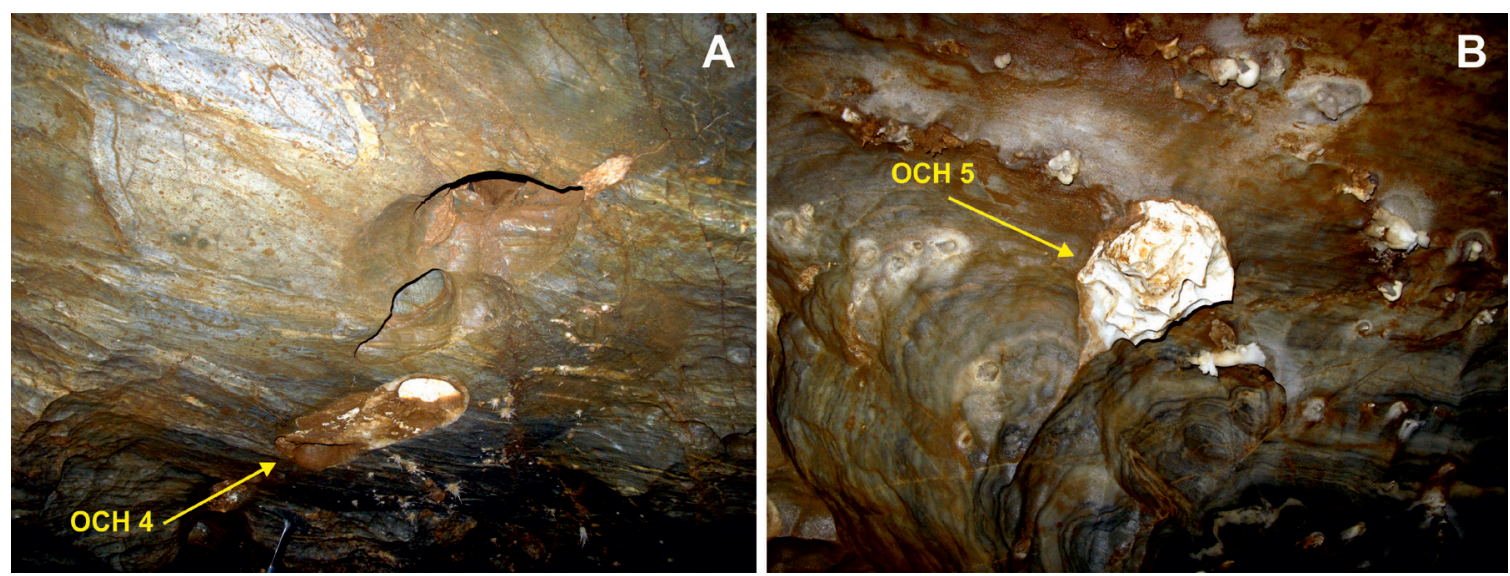

Fig. 3. Position of samples for U-series dating. A) Recrystallized flowstone $(\mathrm{OCH} 4-\mathrm{A})$ truncated by a flat ceiling at the eastern edge of Oválna chodba; B) Corroded aragonite (OCH5-A) on the ceiling of the Hviezdna sieň (for sample positions see Fig. 4) (Photos by P. Bella). 
Both samples were analyzed by the ${ }^{230} \mathrm{Th} /{ }^{234} \mathrm{U}$ method at the U-series Laboratory of the Institute of Geological Sciences of the Polish Academy of Sciences (Warsaw, Poland). The ICP-MS method was used for uranium (U) and thorium (Th) isotope analyses. Chemical separation of $U$ and $T h$ from the carbonate matrix was carried out in the institute following the method described by Hellstrom (2003). Measurements were performed on a double-focusing sector-field ICP MS (Element 2, Thermo-Finngan MAT) in the Department of Geological Processes, Institute of Geology of the Czech Academy of Science, Prague, Czech Republic. The measurement results were corrected for counting background and chemical blank. U-series ages were iteratively calculated from the ${ }^{230} \mathrm{Th} /{ }^{234} \mathrm{U}$ and ${ }^{234} \mathrm{U} /{ }^{238} \mathrm{U}$ activity ratios. All uncertainties, except those associated with decay constants were considered when assessing age uncertainties using error propagation rules.

\section{RESULTS}

\section{High-resolution cave topography and morphology}

The OAC is a subhorizontal maze developed at a ground area of about $30 \times 35 \mathrm{~m}$ limited by the dimensions of marble lens. The cave consists of two morphologically different parts (Fig. 4A): 1) high linear fissure passages and elongated halls with ceiling fissures controlled by steep parallel NE-SW-trending tectonic lines in the western cave segment (Vstupná sieň Hall - Puklinová chodba Passage - Mramorová sien̆ Hall); in the central part (Mliečna cesta Hall), and in the eastern one (Hlboký dóm Chamber) and 2) transverse lower flat-roofed and vaulted passages interconnecting morphologies of the first type (Oválna chodba, Ježovitá chodba, Čarovná chodba, and Priepastovitá chodba passages).

The central part of the cave is mostly horizontal with openings of looped conduits descending below the floor level in places (Priepastovitá chodba and Ježovitá chodba). Numerous higher cupola-shaped depressions and enlarged ceiling fissures reach upwards from a generally horizontal ceiling, which is wider than the floor. The peripheral eastern and western cave segments are tectonically controlled in a larger extend, therefore a vertical span of their uppermost and lowermost points is greater (up to $33 \mathrm{~m}$ ) than in the central part of the cave. The topmost point is situated in the highest part of fissure passage connecting the Vstupná sien and the Mramorová sieñ. Lakes, with oscillating water table, occur in the lowest depressions at the opposite edges of the cave. The area of cave ground plan is $1,335 \mathrm{~m}^{2}$, the inner surface area of underground spaces is $7,064 \mathrm{~m}^{2}$, and their volume reaches $4,424 \mathrm{~m}^{3}$.
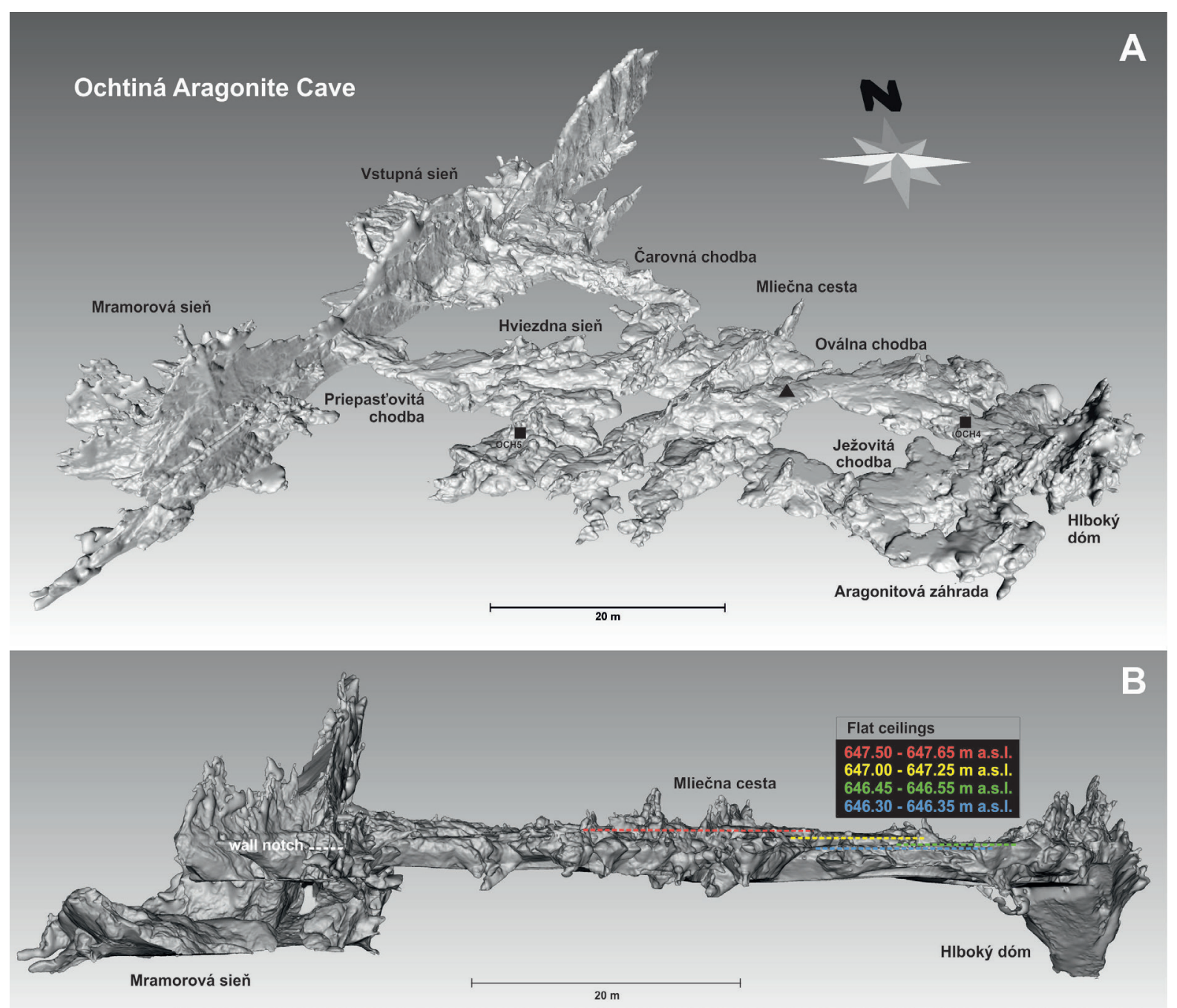

Fig. 4. Ochtiná Aragonite Cave. A) 3D visualization ( $\boldsymbol{\Delta}$ - studied sedimentary profile for the paleomagnetic analysis, - - sampling sites of U-series dating); B) Side projection (W-E) and altitudes of flat ceilings. 
Medium- and small-scale solution morphologies, mainly horizontal flat ceilings (Laugdecken after Biese, 1931), inward-sloping smooth facets (Facetten, planes of repose), ceiling cupola-shaped and smaller spherical depressions, wall notches, as well as spongework-like hollows are typical features of the cave. Flat ceilings occur at several altitude levels: 647.50-647.65 m (the western niche in the Puklinova chodba, the western edge of Oválna chodba), 647.0-647.25 m (the central part of Oválna chodba), 646.45-646.55 m (the eastern edge of Oválna chodba, Aragonitová záhrada Passage), and 646.30-646.35 m (Ježovitá chodba) - mostly in segments of transverse passages with continuously exposed marble in the eastern half of the OAC (Figs. 4 and 5A). The height difference between the lowest and highest flat ceilings is $1.35 \mathrm{~m}$. Flat ceilings consist of several individual fully horizontal surfaces (up to 12.8 $\mathrm{m}^{2}$ ) interrupted by slightly rugged quasi horizontal surfaces (with bedrock protrusions up to $10-15 \mathrm{~cm}$ ), wherein a height difference among fully horizontal surfaces is 10 to $25 \mathrm{~cm}$. If we connect quasi-horizontal and fully horizontal surfaces, the "generalized" surface of the flat ceiling in the Ovalna chodba reaches 34.9 $\mathrm{m}^{2}$ with the greatest at its eastern edge width (up to $5.5 \mathrm{~m}$ ). The largest "generalized" segment of flat ceiling $\left(52 \mathrm{~m}^{2}\right)$ occurs in the Ježovitá chodba and is 3.5-4.5 $\mathrm{m}$ wide. Also, fully horizontal surfaces are sporadically interrupted by small bedrock pyramidal and combshaped pendants.

Transverse passages with flat ceilings associated with solution facets are characterized by triangular cross-sections (Laughöhle profile after Biese, 1931 Oválna chodba) or trapezoidal cross-sections (Ježovitá chodba and Priepastovitá chodba; Fig. 6A, B). In detail, flat ceilings are not directly connected here to inwardsloping smooth facets with a sharp angle. The upper parts of cave walls between flat ceilings and facets are represented by overhanging rounded segments with cusped depressions. Morphostratigraphically, flat ceiling at $646.3 \mathrm{~m}$ asl truncates older cupolashaped and smaller spherical depressions (mostly in the Ježovitá chodba; Fig. 6C).
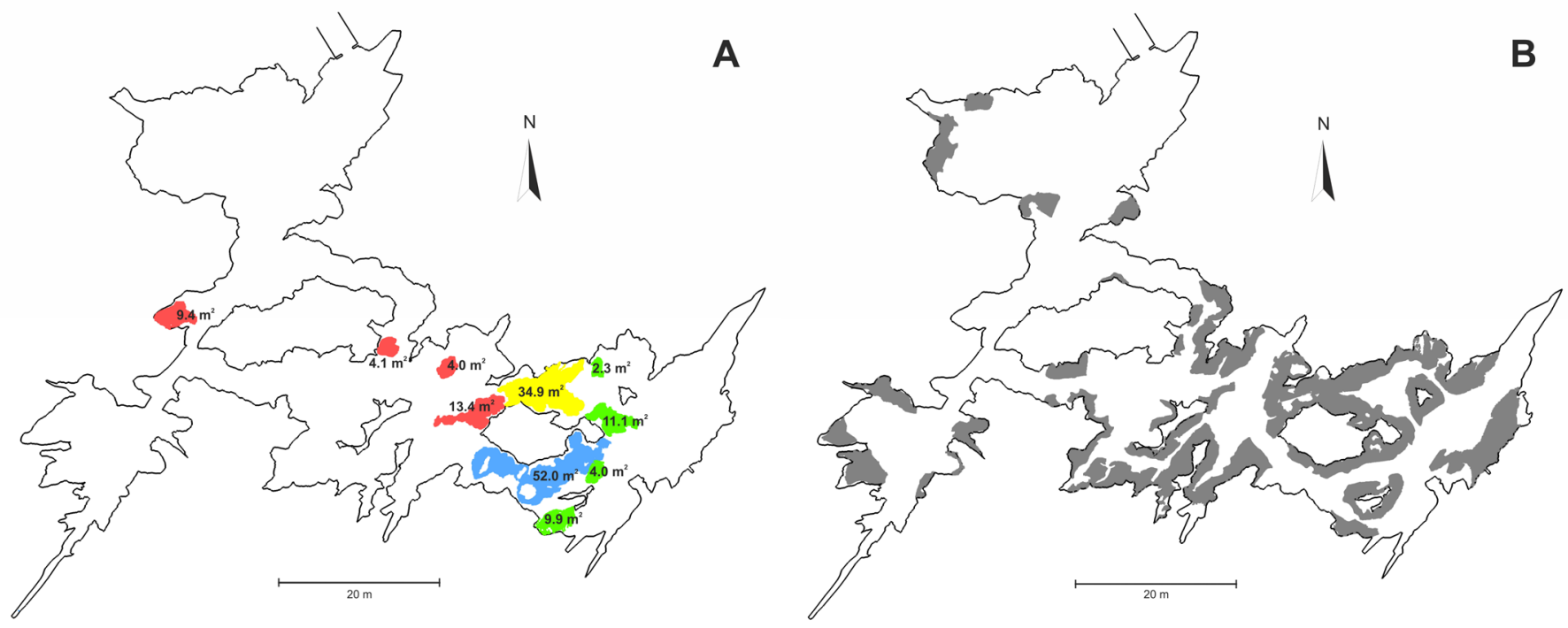

Fig. 5. Occurrence of solution flat ceilings (A) and inward-sloping smooth facets (B). Altitudinal positions of solution flat ceilings: blue 646.30 to $646.35 \mathrm{~m}$ asl, green 646.45 to $646.55 \mathrm{~m}$ asl, yellow 647.00 to $647.25 \mathrm{~m}$ asl, and red 647.50 to $647.65 \mathrm{~m}$ asl.
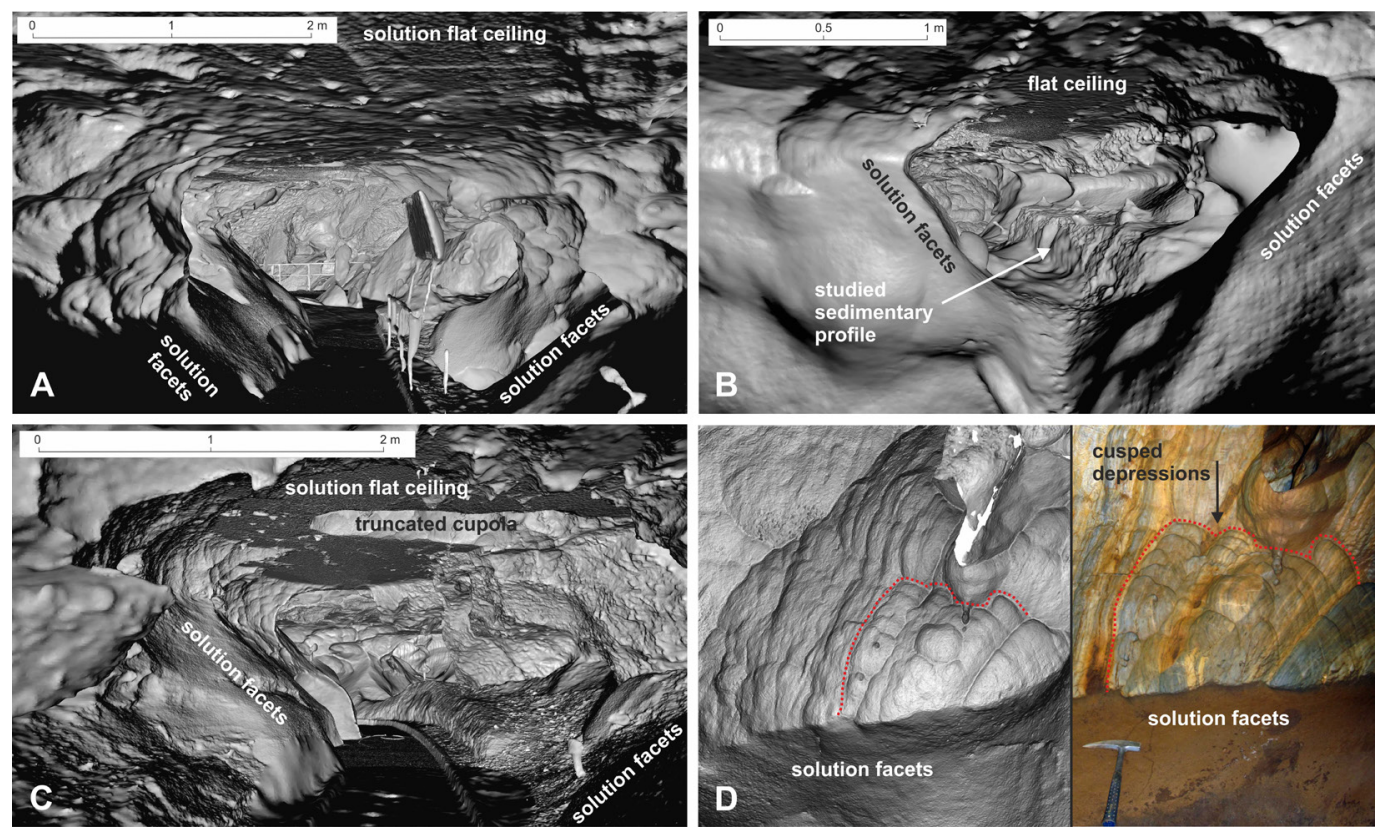

Fig. 6. Passages with a solution flat ceiling and facets. A) Ježovitá chodba; B) Oválna chodba. Cupola-shaped spherical depression truncated by a flat ceiling; C) Ježovitá chodba. Asymmetrical cusped depressions on the cave wall above solution facets; D) Srdce Hrádku Passage (Photo by P. Bella, right). 
Facets as solution inward-inclined smooth wall surfaces generally maintain a slope of $\sim 40^{\circ}-45^{\circ}$, independent of an inclination of marble bedding planes or lamination, which is in accordance with Lange (1963; Figs. 6A-D). Facets developed not only in flat-roofed passages, but also in vaulted (horizontal or inclined) passages and chambers (Fig. 5B), mostly only in the lower parts of bedrock walls (lower halves). The length of the inclined surface of the facets is typically $2-2.5 \mathrm{~m}$, rarely to $4.2 \mathrm{~m}$. The length of the inclined surface of the facets decreases depending on the reduction of the height and width dimensions of passages. The upper edges of facets are not linear at one height level, and they are not separated from upper-lying morphologies by wall water table notches. Facets truncate looped phreatic conduits on the walls or floor of passages in places (Priepastovitá chodba and Ježovitá chodba).

Numerous cusped depressions occur on cave walls above facets, mainly in chambers and wider passages. Their length and width reach dimensions of mostly 5 to $10 \mathrm{~cm}$. They are predominantly asymmetrical, with a shallower part oriented downwards to their lower edge (Fig. 6D). This feature was also documented in a high-resolution cave morphology, result of the TLS and digital photogrammetry (see Pukanská et al., 2020). Such cusped depressions resemble large asymmetrical scallops; therefore, they might be considered as former flow direction indicators.

The water table notch, about $0.4 \mathrm{~m}$ high (646.6$647.0 \mathrm{~m}$ asl) and $0.21 \mathrm{~m}$ deep, extends along the south-eastern wall of the Mramorová sieñ. The notch corresponds to altitudes of flat ceilings in the Oválna chodba and Aragonitová záhrada. Flat ceiling in the Ježovitá chodba is situated $0.3 \mathrm{~m}$ below. Higherlying notches in the ceiling of enlarged fault with tectonic breccia along the south-eastern edge of the Mramorová sieñ are at $648.5 \mathrm{~m}$ asl. The water table notch on the northern wall of the Hlboky dóm is at 643.20-643.55 $\mathrm{m}$ asl, i.e., lower than all flat ceilings, and about $6.5 \mathrm{~m}$ above the water table of the present lake at the chamber bottom (the north-eastern edge of the cave).

\section{High-resolution magnetostratigraphy of sediments}

Re-sampled profile in the Oválna chodba (Fig. 2) consists of layered fine-grained sediments deposited on marble bedrock between two opposite inwardsloping smooth facets (detailed descriptions in Cílek et al., 1998 and Bosák et al., 2002). Sediments represent continuous condensed deposit of infiltration load with no distinct internal hiatuses. The profile top is truncated by younger erosion in vadose conditions.

Successive demagnetization by alternating fields (AF) allowed to derive reliable data of paleomagnetic directions and to determine polarity of magnetic field at the time of deposition, although samples showed low NRM. Mean values of magnetic parameters and standard deviations for pilot 5 samples (1999) and 27 additional samples (2013) are summarized in Table 1. Mean paleomagnetic D and I values (Table 2) in group with $\mathrm{R}$ polarity (1999) show high dispersion $\left(\mathrm{a}_{95}\right)$ in comparison with R-polarized samples of 2013 group due to low number of samples (n) and in group with $\mathrm{R}$ polarity (2013) show higher dispersion than the group with $\mathrm{N}$ polarity due to lower NRM values in the lower part of profile.

Table 1. Magnetic parameters and standard deviations for all samples in Oválna chodba (NRM: natural remanent magnetization; MS: magnetic susceptibility).

\begin{tabular}{|l|c|c|}
\hline Ochtiná Aragonite Cave & $\begin{array}{c}\text { NRM } \\
{[\mathbf{m A} / \mathbf{m}]}\end{array}$ & $\begin{array}{c}\text { MS } \\
{\left[\mathbf{S I}^{*} \mathbf{1 0}^{-6} \text { ] }\right.}\end{array}$ \\
\hline Values & $0.42-72.58$ & $35-1,999$ \\
\hline Mean value & 20.333 & 446.8 \\
\hline Standard deviation & 20.551 & 441.6 \\
\hline Number of samples & 32 & 32 \\
\hline
\end{tabular}

Table 2. Mean paleomagnetic directions for all samples in Oválna chodba (N: normal polarity; R: reverse polarity; D, I: declination, inclination of the remanent magnetization; $a_{95}$ : semi-vertical angle of the cone of confidence calculated according to Fischer (1953) at the 95\% probability level; K: precision parameter; n: number of analyzed samples)

\begin{tabular}{|c|c|c|c|c|c|}
\hline \multirow[t]{2}{*}{ Polarity } & \multicolumn{2}{|c|}{$\begin{array}{c}\text { Mean paleomagnetic } \\
\text { directions }\end{array}$} & \multirow{2}{*}{$a_{95}\left[^{\circ}\right]$} & \multirow[t]{2}{*}{$\mathbf{K}$} & \multirow[t]{2}{*}{$\mathbf{n}$} \\
\hline & $\mathbf{D}\left[{ }^{\circ}\right]$ & I [ $\left.{ }^{\circ}\right]$ & & & \\
\hline $\mathrm{N}$ & 354.28 & 54.03 & 5.55 & 63.58 & 10 \\
\hline $\mathrm{R}$ & 172.69 & -46.41 & 7.86 & 11.76 & 17 \\
\hline
\end{tabular}

Low differences in the NRM and MS values is characteristic for control samples at seven levels from 2013 (Fig. 2), but different contents of magnetic minerals at the same level is indicated (e.g., sample OA41). Interpreted polarities at identical levels correspond; the primary magnetization component $\mathrm{C}$ and the polarity was not determined only in one sample (OA04B). Examples of subsequent AF demagnetization of samples with $\mathrm{N}$ and $\mathrm{R}$ polarities from different profile levels are shown in Figure 7A. The stereographic projections of interpreted paleomagnetic directions of the RM are illustrated in Figure 7B for N-polarized (2013) and R-polarized (1999 and 2013) samples.

According to the IRM, magnetite is career of the magnetization in all samples accompanied by other magnetically harder mineral (hematite; examples in Fig. 7A). The low value of the anisotropy of low-field magnetic susceptibility (AMS) was measured in all samples (Fig. 7C). The dominant direction of magnetic lineation is NE-SW with very low inclination to NW. Anisotropy shape $\mathrm{T}$ has slightly oblate and elongated shape.

Sediments in the upper part of profile showed N magnetic polarity, which Bosák et al. (2002) interpreted as the Brunhes chron $(\mathrm{C} 1 \mathrm{n}$; <0.773 Ma; ages according to Cohen \& Gibbard, 2019). The N/R boundary (Brunhes/Matuyama chron boundary, B/M; Bosák et al. 2002) was more precise determined in 2013 sampling at $13 \mathrm{~cm}$ below the profile's top (between samples OA12 and OA14, with precision of $\pm 1 \mathrm{~cm}$; Fig. 8). Sampling in 1999 was interpreted as $\mathrm{N} / \mathrm{R}$ boundary between samples $\mathrm{OCH} 1(\sim 5 \mathrm{~cm})$ and OCH2 ( 18 cm; Bosák et al., 2002). Sediments at relative levels of $14-53 \mathrm{~cm}$ (OA14 to OA53; 2013) show mostly $\mathrm{R}$ magnetic polarity (deposition during Matuyama Chron; Bosák et al., 2002). The newly 
detected short N-polarized magnetic zone is situated $33 \mathrm{~cm}$ below the top of the profile (OA33). Samples at profile's base (OA55 to OA60) showed unclear polarity, therefore the stratigraphic interpretation is not fully clear. Paleosecular variations are evident between samples OA01 and OA12 (N polarity), as well as between samples OA36 and OA45 (R polarity).

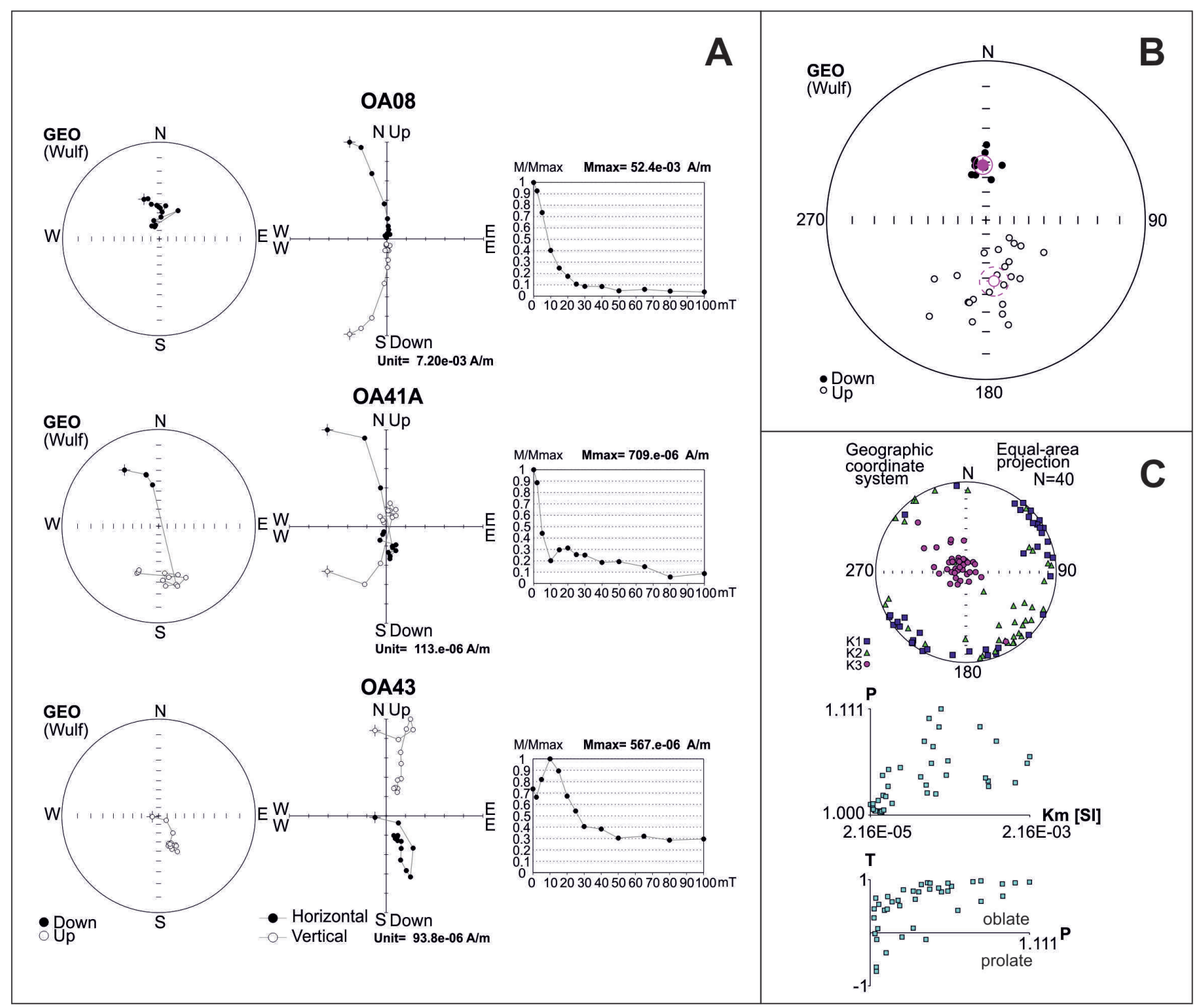

Fig. 7. Examples of the AF demagnetization of samples (A), directions of C-components of remanence (B), and the AMS (C). A up: Sample OA08, normal paleomagnetic polarity; A middle: Sample OA41A reverse paleomagnetic polarity; A down: Sample OA43 reverse paleomagnetic polarity: left circles - a stereographic projection of the natural remanent magnetization, middle - Zijderveld diagram, right boxes - a graph of normalized values of the remanent magnetic moments versus demagnetizing fields; $\mathrm{M}$ - modulus of the remanent magnetic moment of a sample subjected to AF demagnetization (mT); B - direction of ChRM components of remanence of samples with normal and reverse polarity; stereographic projection, open (full) small circles represent projection onto the lower (upper) hemisphere. The mean direction calculated according to Fisher (1953) is marked by a crossed circle, the confidence circle at the $95 \%$ probability level is circumscribed around the mean direction.

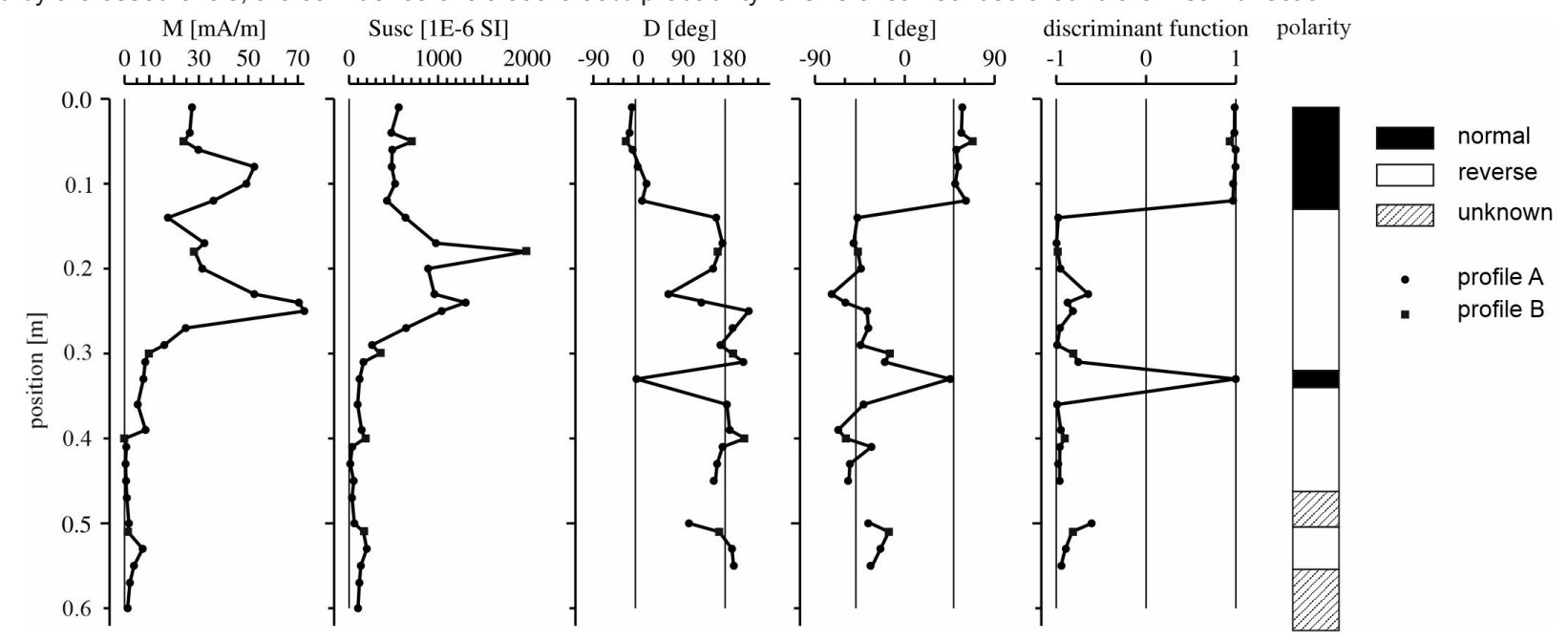

Fig. 8. Principal magnetic and magnetostratigraphy parameters. M: natural remanent magnetization, Susc: magnetic susceptibility, D: declination, I: inclination; paleomagnetic profile: profile A = samples from 1999, profile B = samples from 2013. 


\section{Radiometric ages of speleothems}

Results of U-series analyses of two samples are presented in Table 3. These, along with other published data (Bosák et al., 2002) are used to reconstruct the development phases of the cave. They are characterized by relatively high ${ }^{230} \mathrm{Th} /{ }^{232} \mathrm{Th}$ activity ratio (>300). For the mass spectrometry the threshold value of ${ }^{230} \mathrm{Th} /{ }^{232} \mathrm{Th}$ ratio for "clean samples" is commonly considered at values $200-300$ (Hellstrom, 2006) so for analyzed samples "detrital correction" was not applicable.

Sample OCH4-A (flowstone truncated by a flat ceiling at the eastern edge of Oválna chodba; Fig.
$3 \mathrm{~A})$ has an anomalous ${ }^{230} \mathrm{Th} /{ }^{234} \mathrm{U}$ activity ratio $(>1)$, indicator of an open system. Also, samples JOA 1 and JOA 2 (aragonite recrystallized to calcite) taken from the same flowstone in 1997, had ${ }^{230} \mathrm{Th} /{ }^{234} \mathrm{U}$ ratio higher than 1 (about 1.4; Bosák et al., 2002). All three samples have low $U$ contents $(0.650,2.544$, and $3.553 \mathrm{ppm}$ ), whereas sample OCH5-A (aragonite) has higher U content (11.390 ppm). It suggests uranium leaching from samples JOA 1, JOA 2, and $\mathrm{OCH}-4$ during later processes. Aragonite on the ceiling of the Hviezdna sieñ (OCH5-A; Fig. 3B) is dated to 143.2 \pm 0.6 ka. Its surface was partly corroded during subsequent floods.

Table 3. New U-Th isotopic data used for speleothem dating

\begin{tabular}{|c|c|c|c|c|c|c|c|}
\hline \multirow{2}{*}{ Method } & Sample & $\begin{array}{c}\mathbf{U} \\
{[\mathbf{p p m}]}\end{array}$ & $\begin{array}{c}{ }^{\mathbf{2 3 4}} \mathbf{U} /{ }^{\mathbf{2 3} 8} \mathbf{U} \\
\mathbf{A R}\end{array}$ & $\begin{array}{c}{ }^{230} \mathbf{T h} /{ }^{\mathbf{2 3 4}} \mathbf{U} \\
\mathbf{A R}\end{array}$ & $\begin{array}{c}{ }^{230} \mathbf{T h} /{ }^{\mathbf{2 3 2}} \mathbf{T h} \\
\mathbf{A R}\end{array}$ & $\begin{array}{c}\text { Age } \\
{[\mathbf{k a} \text { BP] }}\end{array}$ & $\begin{array}{c}\text { Initial } \\
{ }^{\mathbf{2 3 4}} \mathbf{U} /{ }^{\mathbf{2 3 8}} \mathbf{U} \mathbf{A R}\end{array}$ \\
\hline \multirow{2}{*}{ ICP-MS } & OCH4-A & $2.544 \pm 0.005$ & $1.033 \pm 0.002$ & $1.729 \pm 0.004$ & $3035 \pm 8$ & & \\
\cline { 2 - 8 } & OCH5-A & $11.39 \pm 0.02$ & $1.324 \pm 0.002$ & $0.761 \pm 0.002$ & $13315 \pm 43$ & $143.2 \pm 0.06$ & $1.4835 \pm 0.0023$ \\
\hline
\end{tabular}

ICP-MS U-series: calculations use the decay constant of Jaffey et al. (1971) for ${ }^{238} \mathrm{U}$, Cheng et al. (2013) for ${ }^{234} \mathrm{U}$ and ${ }^{230} \mathrm{Th}$, and Holden (1990) for ${ }^{232} \mathrm{Th}$. Ages do not include uncertainties associated with decay constants. AR: activity ratio. Error margins quoted are $2 \sigma$ deviations for ICP-MS data. Note: For sample OCH4-A age was not calculated due to U leaching; sample OCH5-A was partly corroded during floods.

\section{INTERPRETATION AND DISCUSSION}

\section{$\mathrm{CO}_{2}$ release during the oxidation of ankerite}

Meteoric waters infiltrating along steep faults caused the dissolution of marble and the weathering (oxidation) of ankerite to Fe oxyhydroxides. However, marble was dissolved to a greater extent due to the $\mathrm{CO}_{2}$ release during ankerite oxidation, i.e., by comparable process described by Kempe (1975, 1998, 2009) in siderite.

Ankerite is sparingly soluble in water. In the presence of water and $\mathrm{CO}_{2}$, its dissolution is much faster because the corresponding bicarbonates are formed, which are soluble in water:

$\mathrm{CaFe}\left(\mathrm{CO}_{3}\right)_{2}+2 \mathrm{CO}_{2}+2 \mathrm{H}_{2} \mathrm{O} \rightarrow \mathrm{Ca}^{2+}+\mathrm{Fe}^{2+}+4 \mathrm{HCO}_{3}^{-}$
$\mathrm{CaFe}\left(\mathrm{CO}_{3}\right)_{2}+2 \mathrm{CO}_{2}+2 \mathrm{H}_{2} \mathrm{O} \rightarrow \mathrm{Ca}\left(\mathrm{HCO}_{3}\right)_{2}+\mathrm{Fe}\left(\mathrm{HCO}_{3}\right)_{2}$
$\mathrm{CaMg}\left(\mathrm{CO}_{3}\right)_{2}+2 \mathrm{CO}_{2}+2 \mathrm{H}_{2} \mathrm{O} \rightarrow \mathrm{Ca}^{2+}+\mathrm{Mg}^{2+}+4 \mathrm{HCO}_{3}^{-}$
$\mathrm{CaMg}\left(\mathrm{CO}_{3}\right)_{2}+2 \mathrm{CO}_{2}+2 \mathrm{H}_{2} \mathrm{O} \rightarrow \mathrm{Ca}\left(\mathrm{HCO}_{3}\right)_{2}+\mathrm{Mg}\left(\mathrm{HCO}_{3}\right)_{2}$

Oxygen, present in water, oxidizes ferrous bicarbonate $\mathrm{Fe}\left(\mathrm{HCO}_{3}\right)_{2}$ to ferric hydroxide, $\mathrm{Fe}(\mathrm{OH})_{3}$ according to equation 5 :

$4 \mathrm{Fe}\left(\mathrm{HCO}_{3}\right)_{2}+\mathrm{O}_{2}+2 \mathrm{H}_{2} \mathrm{O} \rightarrow 4 \mathrm{Fe}(\mathrm{OH})_{3}+8 \mathrm{CO}_{2}$

The products of this reaction are ferric hydroxide, a reddish-brown colloidal substance (goethite, Fig. 9) and a large amount of released $\mathrm{CO}_{2}$, which further contributes to the karstification process represented by the dissolution of surrounding carbonate rocks.

Ankerite contains about 2 wt\% manganese (II), therefore stoichiometric species of $\mathrm{CaMn}\left(\mathrm{CO}_{3}\right)_{2}$ is present. In the presence of water and $\mathrm{CO}_{2}$, this compound will break down (see Equation 6 and 7 ) and form the soluble manganese (II) bicarbonate, which in the presence of oxygen forms dark brown hydrated manganese (III) oxide (Eq. 8). This latter reaction produces $\mathrm{CO}_{2}$ that further dissolves limestone:
$\mathrm{CaMn}\left(\mathrm{CO}_{3}\right)_{2}+2 \mathrm{CO}_{2}+2 \mathrm{H}_{2} \mathrm{O} \rightarrow \mathrm{Ca}^{2+}+\mathrm{Mn}^{2+}+4 \mathrm{HCO}_{3}^{-}[6]$ $\mathrm{CaMn}\left(\mathrm{CO}_{3}\right)_{2}+2 \mathrm{CO}_{2}+2 \mathrm{H}_{2} \mathrm{O} \rightarrow \mathrm{Ca}\left(\mathrm{HCO}_{3}\right)_{2}+\mathrm{Mn}\left(\mathrm{HCO}_{3}\right)_{2}$ [7] $4 \mathrm{Mn}\left(\mathrm{HCO}_{3}\right)_{2}+\mathrm{O}_{2}+\mathrm{H}_{2} \mathrm{O} \rightarrow 2 \mathrm{Mn}_{2} \mathrm{O}_{3} \cdot 5 \mathrm{H}_{2} \mathrm{O}+8 \mathrm{CO}_{2}$ [8]

If more oxygen is available, the oxidation continues to black hydrated manganese (IV) dioxide:

$2 \mathrm{Mn}_{2} \mathrm{O}_{3} \cdot 5 \mathrm{H}_{2} \mathrm{O}+\mathrm{O}_{2} \rightarrow 4 \mathrm{MnO}_{2} \cdot 5 \mathrm{H}_{2} \mathrm{O}$

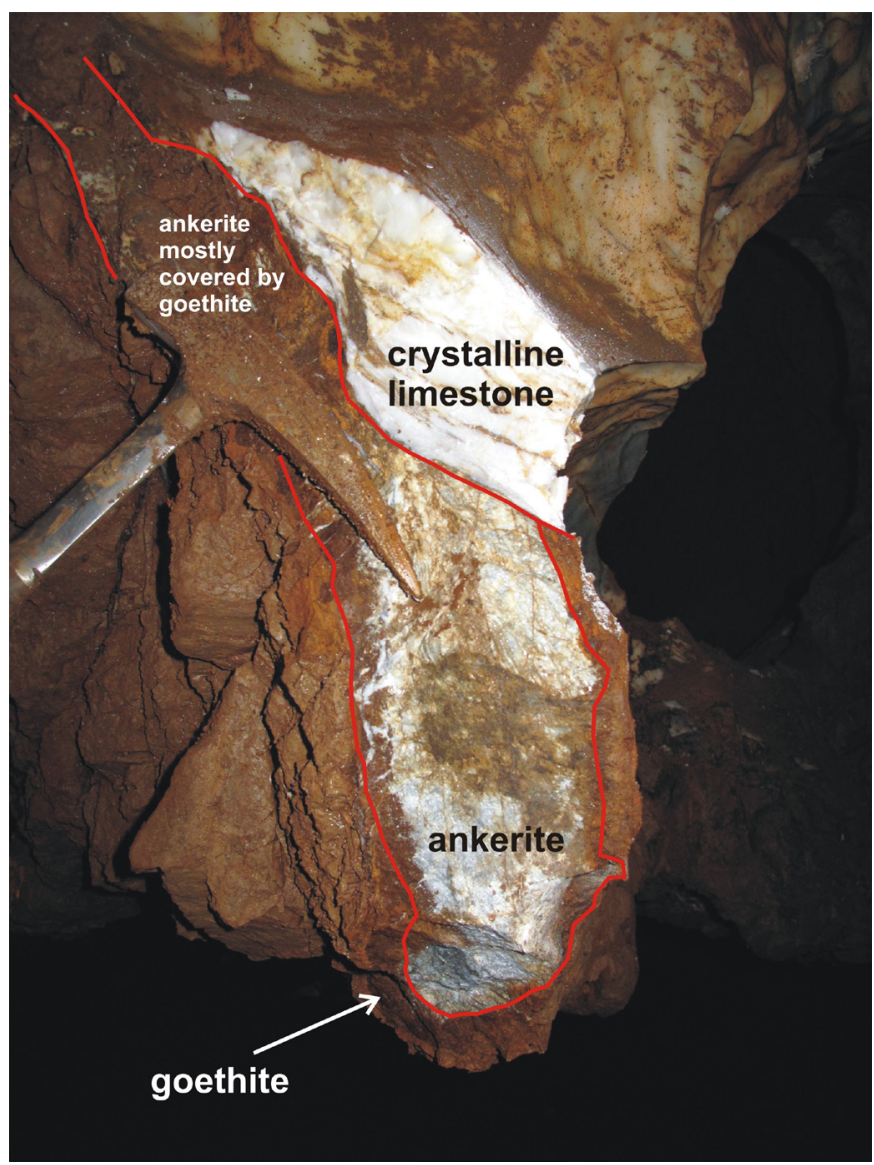

Fig. 9. Crystalline limestone, ankerite, and goethite in Aragonitová záhrada (Photo by P. Bella). 
Mn-rich black layer occurs inside brown clays (a mixture of goethite and clay minerals) in the sediments in the Oválna chodba (Fig. 2) and in the artificial trench of tourist path in the western part of Carovná chodba. The black layer is composed of several bands of hydrated manganese dioxide with abundant intercalations of white allophane and redeposited $\mathrm{Fe}$ oxyhydroxides. Allophane was produced in the acidic environment, probably associated with weathering of sulfides (pyrite) in the surrounding rocks (Cílek et al., 1998; Bosák et al., 2002). Equivalent sedimentary profile with $\mathrm{Fe}$ and $\mathrm{Mg}$ oxyhydroxides, as well as allophane is also exposed in the artificial trench of tourist path in the western part of Carovná Passage.

Rajman et al. (1990, 1993) previously considered that, in addition to the oxidation of ankerite/siderite, also sulfide (pyrite) mineralization in surrounding rocks may have influenced hydrochemical properties of waters seeping into the OAC. However, the absence of gypsum suggests that this cave formed mainly due to the oxidation of ankerite bodies and the dissolution of the surrounding marble supported by $\mathrm{CO}_{2}$, which is released during the oxidation of these calciumferrous and ferrous carbonates (Bosák et al., 2002). This corresponds to the current chemical composition of waters in the cave that have low calcium and magnesium mineralization (Rajman et al., 1990; Peško, 2002; Haviarová \& Peško, 2004). Very acidic (pH 1.9 to 3 ) and strongly mineralized chloride-sulfate waters with a slightly increased temperature $\left(11.7^{\circ} \mathrm{C}\right)$ are recently drained only through the Alžbeta Adit (analyzed by V. Vosáhlo in 1955; see Korpel' \& Kotras, 1957 and Rajman et al., 1990), located southwest of the OAC at the end of the Ochtinský potok Valley.

\section{Origin of solution facets and above-lying cusped depressions}

The OAC is a key locality to study the origin of solution facets on limestone walls. According to Lange (1963), these specific solution rock shapes (referred as "planes of repose") developed during sedimentation of fine-grained particles of insoluble matter on the floor and inward-inclined parts of cave walls, which protect the bedrock from further dissolution (see also Goodman, 1964). Reinboth (1968, 1971) suggests the formation and enlargement of Facetten (solution facets) from upwards at an angle of $45^{\circ}$. He linked their development with the formation of the flat ceiling. However, there is no sharp angle in the corner between them, but an overhanging wall with solution pits. Further, he stated that facets developed because fluid near the ceiling/water table dissolves soluble rock more rapidly than in lower parts of the cavity. According to Gripp (1913), Kempe (1970, 1972), and Kempe et al. (1975), Facetten are created by descending (under-)saturated water.

Gripp (1913), Reinboth (1992), and Kempe (1996a) explained the origin of Facetten in flat-roofed passages with a triangular cross-section in gypsum caves. However, solution facets in the OAC are not associated only with a flat ceiling. They may occur in phreatic conduits with oval or vaulted ceiling without any re-shaping by later processes. They were also noticed around chambers without flat ceilings, in small wall niches even in several height positions in the same passage or chamber. In flat-roofed passages of the OAC, the corner between solution facets and flat ceiling is represented by overhanging wall with solution hollows or cusped depressions.

Cusped depressions and lower-lying inwardsloping smooth solution facets (Fig. 6) show that these morphologically different and sharply bounded wall-rock shapes originated by limestone dissolution under different conditions. Asymmetrical cusped depressions indicate their development by downward slowly moving water, whereas smooth facets are covered by a protective coating accumulated from suspended $\mathrm{Fe}$ oxyhydroxides (Fig. 6D). In phreatic conduits with stagnant or almost stagnant water, natural water convection resulted from the density difference between solutions at limestone walls and in the bulk of water body. While water at the dissolving surface moves downward (an increase in solution density along exposed limestone surfaces), within the bulk fluid is opposite motion - upward (Curl, 1966; see also Gripp, 1913). In the transverse passages of the OAC, the bedrock floor and flat ceilings are not controlled and dissected by central vertical fracture as assumed by models of Grip and Kempe. It is more likely that solution facets in the OAC were probably developed by limestone dissolution under conditions of slowly downward moving water, possibly accompanied by deposition of insoluble fine-grained particles (sensu Lange, 1963, 1968).

\section{Origin of solution flat ceilings}

The origin of a horizontal ceiling along the water table was described by Gripp (1913), but in gypsum caves. Lange (1962) stated that when the water table remains nearly constant, solution planed ceilings in limestone caves can be developed along the surface of a cave lake (by so-called "ceiling planation"). The formation of flat ceilings in caves in connection with external or internal erosion base was also discussed by Cocean $(1975,1979)$.

In the OAC, solution flat ceilings occurring at different elevations are associated with solution inward-sloping smooth facets, i.e., they were developed in the flatroofed passages, but with no sharp angle between facets and flat ceiling. Therefore, flat ceilings were probably formed closely below the slightly oscillating water table (as assumed by Reinboth, 1968, 1971 and Kempe et al., 1975; see also Gechter et al., 2008). The wider horizontal wall notch in the Mramorová sieñ (Fig. 4B) that occur at the same altitude as the flat ceiling in the Ježovitá chodba, indicates a slight water table oscillation during its formation. Solution experiments with salt models by Reinboth (1992) showed that the solution at the Laugdecke is about twice faster than the solution at a vertical wall and about three times faster than on upward-facing surface. Flat ceilings seem to develop if the solution is fast, i.e., in low-saturated water (Kempe, 1996a). Undersaturated groundwater moving through the fractured insoluble rocks from the surrounding area penetrates the karstified marble lens. Since this water has a lower density, it is 
concentrated in the upper part of the water column. In several places, small bedrock pyramidal and combshaped pendants protrude downwards from the flat ceilings, which have not been completely removed by the lateral enlargement/corrosion of the ceiling.

\section{Magnetostratigraphy and morphogenetic implications}

Magnetostratigraphy (both on pilot samples and high-resolution) proved $\mathrm{N}$ magnetic polarity in the upper part of profile. It is interpreted as the Brunhes chron (C1n; <0.773 Ma). The N/R boundary (C1n/ $\mathrm{C} 1 \mathrm{r}$ ) is linked to the $\mathrm{B} / \mathrm{M}$ chron boundary already by Bosák et al. (2002). R-polarized sediments below the N/R boundary represent the Matuyama chron. The newly detected short N-polarized magnetic zone inside the R-polarized Matuyama chron at $33 \mathrm{~cm}$ below the top of the profile (OA33) is interpreted here as the Jaramillo event $(\mathrm{C} 1 \mathrm{r} .1 \mathrm{n}, 0.990-1.071$ $\mathrm{Ma}$. To support this interpretation, we compared mean paleomagnetic directions (D, I) from the Oválna chodba with the segment of identical age in the Domica Cave, which is situated only $\sim 30 \mathrm{~km}$ to SSE (Bella et al., 2019; Table 4). The newly calculated counter-clockwise paleorotation (CCW) values both for N- and R-polarity segments are nearly identical in both sediment segments. R-polarities in the Domica Cave have larger dispersion, but still within $\mathrm{a}_{95}{ }^{\circ}$ values. Higher $\mathrm{CCW}$ rotations in R-polarized segment than in $\mathrm{N}$-polarized one generally correspond to published data for Pannonian-Carpathian domain (Krs \& Pruner, 1999; Márton et al., 2015). Domica data show higher CCW values also due to fact, that evaluated R-polarized segment below the $\mathrm{B} / \mathrm{M}$ boundary is longer than in the OAC. Mean paleomagnetic directions and the $\mathrm{CCW}$ values both in the Domica Cave and in the OAC strongly support our magnetostratigraphy interpretation for sediments in the Oválna chodba. Short-lasted N excursions below the B/M boundary (i.e., Kamikatsura at $0.885 \mathrm{Ma}$, Santa Rosa at $0.932 \mathrm{Ma}$, cf. Gibbard and Cohen, 2019) hardly can be recorded in this type of phreatic clays and size of sampling boxes. Samples at profile base (OA55 to OA60) showed unclear polarity, therefore the stratigraphic interpretation is not fully clear; they might even represent the transition to Olduvai subzone ( $\mathrm{C} 2 \mathrm{n}, 1.780$ to $1.925 \mathrm{Ma})$. The sedimentary profile is truncated by erosion in the vadose zone and unconformably covered by flowstone ( 177 ka - sample JOA3; Pruner et al., 2000; Bosák et al., 2002) constraining the youngest possible age of Oválna chodba sediments.

Table 4. Mean paleomagnetic directions and rotations (present declination value of $2^{\circ}$ is included in the CCW calculation).

\begin{tabular}{|c|c|c|c|c|c|c|}
\hline \multirow{2}{*}{ Cave } & \multirow{2}{*}{$\mathbf{n}$} & \multirow{2}{*}{ Polarity } & \multicolumn{2}{|c|}{ Mean paleomagnetic directions } & \multirow{2}{*}{$a_{95}\left[^{\circ}\right]$} & \multirow{2}{*}{$\mathrm{CCW}\left[{ }^{\circ}\right]$} \\
\hline & & & D ['] & I [ ['] & & \\
\hline Ochtiná & 9 & $\mathrm{~N}$ & 355.91 & 52.23 & 5.14 & 6.09 \\
\hline Domica & 51 & $\mathrm{~N}$ & 355.44 & 56.26 & 3.61 & 6.56 \\
\hline Ochtiná & 23 & $\mathrm{R}$ & 172.51 & -47.81 & 8.39 & 9.49 \\
\hline Domica & 59 & $\mathrm{R}$ & 166.93 & -47.24 & 4.27 & 15.07 \\
\hline
\end{tabular}

The calculated and estimated/interpolated depositional rates of individual segments of profile in Oválna chodba are based on dated paleomagnetic boundaries (from the B/M boundary at $0.773 \mathrm{Ma}$; up to Jaramillo base at $1.071 \mathrm{Ma}$ ) and continuous deposition without any hiatuses (Table 5). Top of Jaramillo (0.990 Ma) subzone is roughly equal to upper boundary of Mn-rich horizon with asbolane/allophane. The values for upper part (to Jaramillo top) and profile base (below Jaramillo base) are slightly below $0.09 \mathrm{~cm} / \mathrm{kyr}$ (Table 5). Mn-rich layer indicates even lower depositional rates (slightly below $0.03 \mathrm{~cm} / \mathrm{kyr}$ ).

The prevailing NE-SW direction of magnetic lineation from AMS measurements indicates uniform direction of water flow during the accumulation of sediments, i.e., from the Hlboký dóm through the Oválna chodba to the Mliečna cesta. The low depositional rate of clays and silty clays above and below $\mathrm{Mn}$-rich zone resulted from very slow water movement in confined conditions in marbles completely enclosed by phyllites and with no direct relation to the surface. Only occasionally turbid water seeped through crystalline rocks was loaded in extremely fine-grained infiltration material, autochthonous $\mathrm{Fe}$ oxyhydroxides and negligible coarser-sized allogenic input (see in Bosák et al., 2002). Much slower depositional rate of Mn-rich layers probably resulted from slow chemical reactions and precipitation on Mn-bearing minerals (although also mixed with input of infiltration load). Calculated and estimated data from Table 5 might indicate that the deposition in the Oválna chodba profile started not sooner than $\sim 1.8 \mathrm{Ma}$ ago. The unclear paleomagnetic polarity of basal samples (OA55A-B to OA60) and $\mathrm{N}-\mathrm{R}$ polarity of sample OA55 might support this calculation. These samples could represent the top of the Olduvai magnetic subzone (C2n, 1.780-1.925 $\mathrm{Ma}$ ), if depositional rates below Jaramillo base were not higher than presented in Table 5. The age of flowstone covering the sediments is $\sim 177$ ka (Bosák et al., 2002), therefore described sediments were eroded in fully vadose conditions between $<630$ and $>177$ ka (Table 5) by multiple oscillating and mowing groundwater in the lower parts of the $\mathrm{OAC}$, similar to the present hydrological situation.

The prevailing NE-SW direction of magnetic lineation from AMS measurements indicates uniform direction of water flow during the accumulation of sediments, i.e., from the Hlboký dóm through the Oválna chodba to the Mliečna cesta.

\section{Updated reconstruction of an origin and development of the cave}

The OAC began to develop under confined phreatic conditions in marble completely enclosed by phyllites. Mostly fault-controlled infiltration of oxygenated water from surface through phyllites and other 
metamorphic rocks caused oxidation of ankerite to $\mathrm{Fe}$ oxyhydroxides accompanied by $\mathrm{CO}_{2}$ release. Dating of sediments indicates that the beginnings of cave formation can be placed in Pliocene-Early Pleistocene (Tables 5 and 6). The primary cavities were enlarged by the dissolution of marble around bodies of decomposed ankerite. Following their gradual enlargement, horizontal passages developed, through which the fissure parts of the cave formed along parallel faults (Mramorová sieñ - Vstupná sieň, Mliečna cesta, and Hlboký dóm) were interconnected. Irregular niches and cupola-shaped depressions are remnants of older cavities, which were formed by marble dissolution under conditions of very slow density-driven convectional cellular water circulation when water body operated probably close to the saturation (see Kempe, 1996b).

Fine-grained infiltration sediments and suspended Fe oxyhydroxides were deposited on the floor and bedrock walls inclined to $\sim 5^{\circ}$. Because these materials are poorly permeable to impermeable, their presence prevented the dissolution of the underlying marble surfaces. Therefore, the corrosion occurred only on the exposed (uncovered) parts of marble walls and ceilings. Inward-sloping smooth bedrock surfaces enlarged from the bottom up and were covered with a protective coating accumulated from suspended Fe oxyhydroxides (see Lange, 1963).

Table 5. Calculated and estimated/interpolated depositional rates and duration of deposition of individual segments in the Oválna chodba.

\begin{tabular}{|c|c|c|c|c|c|}
\hline \multirow{2}{*}{ Profile segment } & \multirow{2}{*}{$\begin{array}{l}\text { Vertical } \\
\text { distance } \\
{[\mathrm{cm}]}\end{array}$} & \multirow{2}{*}{ Age $[\mathrm{Ma}]^{\S}$} & \multicolumn{2}{|c|}{ Period } & \multirow{2}{*}{$\begin{array}{c}\text { Depositional } \\
\text { rate } \\
{[\mathrm{cm} / \mathrm{kyr}]}\end{array}$} \\
\hline & & & {$[\mathbf{M y r}]$} & [Ma] & \\
\hline $\begin{array}{l}\text { Profile top - } \\
\text { Brunhes base }\end{array}$ & 13 & $>0.177-<0.773$ & $\leq 0.145^{*}$ & $\leq 0.630-0.773^{*}$ & $0.088^{*}$ \\
\hline $\begin{array}{l}\text { Matuyama top - Jaramillo } \\
\text { top }\end{array}$ & 19 & $0.773-0.990$ & 0.217 & $0.773-0.990$ & 0.088 \\
\hline $\begin{array}{l}\text { Jaramillo top - Jaramillo } \\
\text { base }\end{array}$ & 2 & $0.990-1.071$ & 0.81 & $0.990-1.071$ & 0.028 \\
\hline $\begin{array}{l}\text { Jaramillo base - } \\
\text { base of Mn-rich layer }\end{array}$ & 16 & $>1.071$ & $\sim 0.570^{*}$ & $1.071-\sim 1.640^{*}$ & $0.028^{*}$ \\
\hline lower clay & 12 & - & $\leq 0.180^{*}$ & $1.640-\leq 1.820^{*}$ & $0.088^{*}$ \\
\hline
\end{tabular}

spaleomagnetic boundaries (Gibbard \& Cohen, 1999) and U-series dating (Bosák et al., 2002);

*estimated/interpolated values refer to identical sediment environment as in calculated segments.

Sediments studied in the lower part of the Oválna chodba began to accumulate on its bottom bedrock in fully phreatic conditions in confined aquifer before $1.071 \mathrm{Ma}$, most probably not later than $1.8 \mathrm{Ma}$ ago (Early Pleistocene, Table 5); the formation of this passage must have ended in this time. Layers with allophane, product of sulfide weathering, started to deposit at $\sim 1.6 \mathrm{Ma}$ and ceased their accumulation roughly at $0.990 \mathrm{Ma}$ (the end of the Jaramillo magnetic subzone; Table 5). The flowstone covering the sediments dated to $\sim 177 \mathrm{ka}$, deposited already in vadose conditions.

Epiphreatic horizontal wall notches have formed along the slightly oscillating and long-lasting stagnation groundwater table and flat ceilings (Laugdecken) closely below it. Primary phreatic cavities were substantially enlarged. Many irregular cupola-shaped depressions and spongework-like hollows are relics of primary phreatic morphologies and are still preserved above flat ceilings and on sides of main passages.

Remnants of corroded aragonite in some cupolashaped depressions were truncated by younger horizontal flat ceilings. They date the evolution of flat ceiling at $646.5 \mathrm{~m}$ asl in the short passage between the Oválna chodba and Hlboký dóm. Flat ceiling cut the older ceiling cavity between $\sim 450$ and $>177 \mathrm{ka}$ (Bosák et a., 2002), i.e., after partial erosion of finegrained sediments. Thus, sediments in the Oválna chodba were eroded between $\sim 680$ and $>450 \mathrm{ka}$ by periodic and multiple groundwater table oscillations. Solution of inward-sloping smooth bedrock surfaces (facets) developed during the major enlargement phase/phases of passages and chambers and they truncate looped conduits (Bella, 2004).
The dated aragonite with a corroded surface at $646.7 \mathrm{~m}$ asl (sample OCH5-A) suggests that the cave was once again flooded up to its ceiling after $143 \mathrm{ka}$. This is documented by the thin Fe oxyhydroxides coating accumulated on the $177 \mathrm{ka}$ old flowstone in the Oválna chodba. Also, corrosion vugs in aragonite (138-121 ka old - samples 90/Och2A and 90/Och2B) contain allogenic admixture of mica and quartz (Bosák et al., 2002). The lower part of cupola-shaped depressions truncated by a flat ceiling were flooded even later as the perimeter of depressions is coated by thin accumulations of $\mathrm{Fe}$ oxyhydroxides. The upper part of cupolas served as "air traps" and do not contain allogenic coatings but are instead decorated with white aragonite formations (e.g., in the Ježovitá chodba). Younger aragonite generations with ages $\leq 14$ ka (samples 90/Och1 and 95/Och1A; Bosák et al., 2002) are not corroded, meaning that later oscillations of groundwater floods were less ample. At present, the lake water table in OAC's lower part oscillates within 3-4 m, depending on the amount of surface precipitation.

The aragonite generation that is $\sim 121$ ka corresponds to MIS 5e, whereas the one of $\sim 13.5 \mathrm{ka}$ corresponds to the Allerød oscillation, nearly at the end of the last glacial period (MIS 2). The youngest generation of aragonite is still forming (MIS 1; Cílek et al., 1998; Bosák et al., 2002).

\section{Type of speleogenesis}

Water that has derived its aggressiveness from sources unrelated to surface, i.e., from depths (Palmer 1991, 2007, 2011; Ford \& Williams, 2007), represents one of the basic criteria to distinguish hypogenic caves. Kempe (2009) and Kempe et al. 
(2016) classified caves formed by processes driven by $\mathrm{CO}_{2}$ released during ankerite/siderite oxidation at depth, as hypogenic, defining a specific subtype of non-ascending hypogenic speleogenesis. However, according to Webb (2020), such caves are termed supergene, because generation of the acidity is due to near-surface oxidation and they are the result of shallow meteoric waters circulation and not by ascending waters, where the source is at depth beneath the cave. Following these inconsistent definitions, the OAC may be rather classified as a supergene cave, since it was not formed by waters ascending from the depth andthe aggressiveness of waters was derived from near-surface source.

Table 6. Main development phases of the Ochtiná Aragonite Cave (updated from Bosák et al., 2002; see also Figure 10).

\begin{tabular}{|c|c|c|}
\hline Development phases & Cave morphology and sediments & Period \\
\hline Initial phreatic & $\begin{array}{l}\text { Individual primary phreatic cavities originated along parallel } \\
\text { steep fractures }\end{array}$ & \multirow[b]{2}{*}{$\begin{array}{l}\text { Late Tertiary - Early } \\
\quad \text { Pleistocene }\end{array}$} \\
\hline Phreatic & $\begin{array}{l}\text { Enlargement of primary cavities to larger voids and conduits, } \\
\text { their interconnection through transverse conduits, formation } \\
\text { of solution facets, and ceiling cupola-shaped depressions and } \\
\text { spongework-like hollows }\end{array}$ & \\
\hline \multirow{12}{*}{ Epiphreatic - vadose } & $\begin{array}{l}\text { Formation of the upper solution flat ceiling (Ovalna chodba) } \\
\text { closely below the "stabilized" water table, ongoing formation of } \\
\text { solution facets and phreatic cavities and conduits in the lower } \\
\text { lying, still flooded part of the cave, the highest parts of the steep } \\
\text { fissures above the groundwater table began to be sculpted by } \\
\text { seeping meteoric water }\end{array}$ & Early Pleistocene \\
\hline & Sediment accumulation started (in the Oválna chodba) & $<1.8 \mathrm{Ma}$ \\
\hline & $\begin{array}{l}\text { Allophane deposition in the middle part of the sedimentary profile } \\
\text { (allophane was produced in the acidic environment, probably } \\
\text { associated with sulfide weathering) }\end{array}$ & $\leq 0.9-\sim 1.6 \mathrm{Ma}$ \\
\hline & Water table drop below middle part of the Oválna chodba & Middle Pleistocene \\
\hline & Erosion of sediments & $<630-\sim 500 \mathrm{ka}$ \\
\hline & $\begin{array}{l}\text { Precipitation of the oldest dated generation of aragonite in cavities } \\
\text { above the water table (kidney-shaped forms), recrystallization of } \\
\text { aragonite to calcite }\end{array}$ & $\sim 500-\sim 450 \mathrm{ka}$ \\
\hline & $\begin{array}{l}\text { formation of the lower-lying solution flat ceilings (Ježovitá } \\
\text { chodba) and wall notches (Mramorová sieñ and adjacent cave } \\
\text { parts) closely below the repeatedly "stabilized" water table, final } \\
\text { formation of solution facets and phreatic cavities and conduits in } \\
\text { the lower-lying, still flooded part of the cave, ongoing enlargement } \\
\text { of the highest parts of the steep fissures above the groundwater } \\
\text { table by meteoric water }\end{array}$ & $\sim 450->177 \mathrm{ka}$ \\
\hline & $\begin{array}{l}\text { Precipitation of flowstone on eroded surface of redeposited Fe } \\
\text { oxyhydroxides (e.g., Oválna chodba) }\end{array}$ & $177 \mathrm{ka}$ \\
\hline & $\begin{array}{l}\text { Precipitation of the second aragonite generation (kidney-shaped } \\
\text { forms), only partly recrystallized to calcite }\end{array}$ & $143-121 \mathrm{ka}$ \\
\hline & $\begin{array}{l}\text { Water table oscillations and repeated floods of the lower-lying } \\
\text { cave parts (up to the ceiling level of the Hviezdna sieñ), formation } \\
\text { of wall notch in the Hlboky dom along the stabilized water table } \\
\text { (approximately at the position of the floor of transverse corridors), } \\
\text { the surface of the older aragonite generations was corroded } \\
\text { by floodwater (corrosion vugs in 138-121 ka old speleothems } \\
\text { contain mica and quartz) }\end{array}$ & Late Pleistocene \\
\hline & $\begin{array}{l}\text { Precipitation of the third aragonite generation (acicular and } \\
\text { spiral forms) }\end{array}$ & $\sim 13.5 \mathrm{ka}$ \\
\hline & $\begin{array}{l}\text { Precipitation of the youngest aragonite generation ("frostwork" } \\
\text { in the sense of Hill \& Forti, 1995), water table oscillations to a } \\
\text { height of } 3-4 \mathrm{~m} \text { and repeated floods on the accumulation floor } \\
\text { of the lowest-lying cave parts (flat floor of Vstupná sieñ, inclined } \\
\text { floor of the Hlboký dóm) }\end{array}$ & Holocene - Recent \\
\hline
\end{tabular}
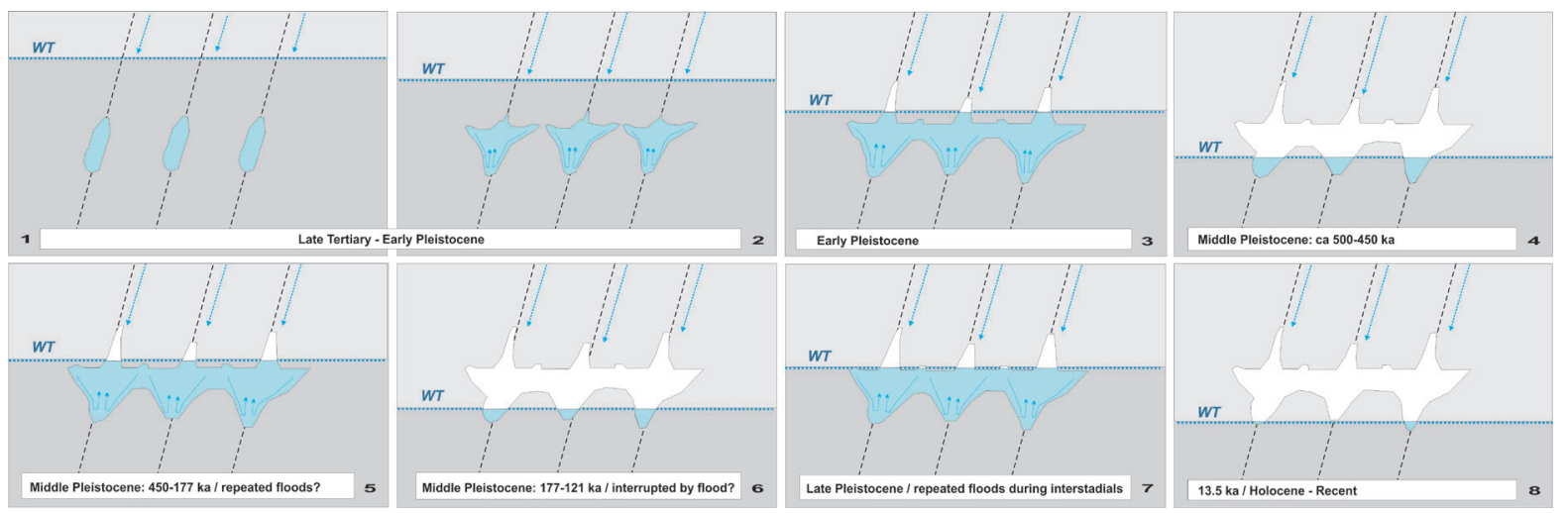

Fig. 10. Simplified sketch of the Ochtiná Aragonite Cave development. WT: groundwater table; for details see Table 6. 


\section{CONCLUSIONS}

The OAC is a one of the most representative examples of a cave formed in a lens of crystalline limestone and ankerite completely enclosed by phyllites. Its origin was controlled by several parallel steep faults along which meteoric water percolated underground. The ankerite was oxidated to various $\mathrm{Fe}$ and $\mathrm{Mn}$ oxyhydroxides producing $\mathrm{CO}_{2}$ that inn turn enhanced dissolution of marble. Many cupolashaped depressions and irregular spongework-like hollows of phreatic origin contrast with solution flat ceilings formed at multiple elevations just below the former stabilized, but slightly oscillated groundwater table during its interrupted descent. Flat ceilings occur mainly in transverse horizontal passages that interconnect parallel fault-controlled passages and halls. Older cupola-shaped depressions are truncated by flat ceilings. Inward-sloping smooth solution facets were probably developed by the limestone dissolution under conditions of slowly moving or stagnant water, possibly assisted by the sedimentation of insoluble fine-grained rock particles, i.e., they represent socalled the "planes of repose". Their smooth surfaces, inclined at an angle of about $45^{\circ}$, are covered by thin $\mathrm{Fe}$ oxyhydroxides coatings. Inward-sloping smooth facets occur in the flat-roofed passages, as well as in the passages and halls with a vaulted ceiling. Cave sediments deposited from slow moving water in confined phreatic conditions. Jaramillo magnetozone (0.990-1.071 Ma) and the Brunhes/ Matuyama boundary $(0.773 \mathrm{Ma})$ were recorded in the Oválna chodba profile. The slow depositional rates ( $0.09 \mathrm{~cm} / \mathrm{kyr}$, and $0.03 \mathrm{~cm} / \mathrm{kyr}$ in Mn-rich horizon) calculated from magnetostratigraphy, correspond to depositional environment under confined phreatic conditions. Transition from phreatic to epiphreatic and vadose zones occurred 630 to 500-450 ka. Older generation of aragonite formations (with ages $~ 500-$ $450 \mathrm{ka}$ and $143-121 \mathrm{ka}$ ) were corroded during older repeated floods. Aragonite formations younger than $13.5 \mathrm{kyr}$ are not corroded because the last repeated floods oscillate only in the lower parts of the cave.

\section{ACKNOWLEDGEMENTS}

This work was supported by the grants VEGA No. 1/0146/19 and KEGA No. 004TUKE-4/2019, and institutional financing of the Czech Academy of Sciences, Institute of Geology (no. RVO67985831) and the State Nature Conservancy of the Slovak Republic, Slovak Caves Administration. Thanks to Stanislav Šlechta, Štefan Rákay jr., Leoš Zamborský and Peter Gažik for assistance with field works and measurements. Many thanks to reviewers and the editor for their useful comments and suggestions.

Authorship statement: PBE and PBO designed and directed the study; LG studied the cave geology and $\mathrm{PBE}$ the cave morphology; KP and KB performed the terrestrial laser scanning, digital photogrammetry and $3 \mathrm{D}$ visualization of the cave; PP, PBO and ŠK performed the paleomagnetic analysis of cave sediments and its interpretation; $\mathrm{HH}$ performed the U-Th dating of speleothems; DH analyzed the chemistry of cave waters; PT interpreted the chemogenesis; PBE and $\mathrm{PBO}$ reconstructed an origin and development of the cave. $\mathrm{PBE}$ and $\mathrm{PBO}$ wrote the paper with input from all authors.

\section{REFERENCES}

Abonyi, A., Abonyiová, M., 1981. Magnezitové ložiská Slovenska. Mineralia Slovaca. Monografia 1, Bratislava, 125 p.

Bajaník, Š., Hanzel, V., Ivanička, J., Mello, J., Pristaš, J., Reichwalder, P., Snopko, L., Vozár, J., Vozárová, A., 1983. Vysvetlivky ku geologickej mape Slovenského rudohoria - východ, 1:50.000. GÚDŠ, Bratislava, 223 p.

Bella, P., 1998. Morfologické a genetické znaky Ochtinskej aragonitovej jaskyne. Aragonit, 3, 3-7.

Bella, P., 2004. Geomorfologické pomery Ochtinskej aragonitovej jaskyne. Slovenský kras, 42, 57-88.

Bella, P., Bosák, P., Braucher, R., Pruner, P., Hercman, H., Minár, J., Veselský, M., Holec, J., Léanni, L., 2019. Multi-level Domica-Baradla cave system (Slovakia, Hungary): Middle PliocenePleistocene evolution and implications for the denudation chronology of the Western Carpathians. Geomorphology, 327, 62-79. https://doi.org/10.1016/ j.geomorph.2018.10.002

Bella, P., Zelinka, J., Peško, M., Gažik, P., 2000. Natural phenomena and protection of the Ochtina Aragonite Cave (Slovakia). In: Song, L. (Ed.), Show Caves Protection and Restoration. Proceedings, YaolinTonglu, p. 22-36.

Biese, W., 1931. Über Höhlenbildung, I. Teil. Entstehung der Gipshölen am südlichen Harzrad und am Kyffhäuser. Abhandlung der Preußischen Geologischen Landsanstalt, NF, 137, Berlin, 71 p.

Bolitho, M., Kazhdan, M., Burns, R., Hoppe, H., 2007. Multilevel Streaming for Out-of-Core Surface Reconstruction. In: Belyaev, A., Garland, M. (Eds.), Proceedings of the 5th Eurographics Symposium on Geometry Processing (Barcelona, Spain, 4-6 July 2007), p. 69-78.

Bosák, P., Bella, P., Cílek, V., Ford, D.C., Hercman, H., Kadlec, J., Osborne, A., Pruner P., 2002. Ochtiná Aragonite Cave (Western Carpathians, Slovakia): Morphology, Mineralogy of the Fill and Genesis. Geologica Carpathica, 53(6), 399-410.

Bosák, P., Pruner, P., Kadlec, J., 2003. Magnetostratigraphy of cave sediments: application and limits. Studia Geophysica et Geodaetica, 47(2), 301-330.

https://doi.org/10.1023/A:1023723708430

Bystrický, J., Fusán, O. 1954. Geologické pomery Hrádku pri Štítniku. Geologický sborník, 5(1-4), 140-143.

Cílek, V., Bosák, P., Melka, K., Žák, K., Langrová, A., Osborne, A., 1998. Mineralogické výzkumy v Ochtinské aragonitové jeskyni. Aragonit, 3, 7-12.

Chadima, M., Hrouda, F., 2006. Remasoft 3.0 - A userfriendly paleomagnetic data browser and analyser. Travaux Géophysiques, XXVII, 20-21.

Cheng, H., Edwards, R.L., Shen, C-C., Polyak, V.J., Asmerom, Y., Woodhead, J., Hellstrom, J., Wang, Y., Kong, X., Spötl, C., Wang, X., Alexander, E.C., 2013. Improvements in ${ }^{230} \mathrm{Th}$ dating, ${ }^{230} \mathrm{Th}$ and ${ }^{234} \mathrm{U}$ half-live values, and U-Th isotopic measurements by multi-collector inductively coupled plasma mass spectrometry. Earth and Planetary Science Letters, 371-372, 82-91.

https://doi.org/10.1016/j.eps1.2013.04.006 
Choppy, J., 1994. La première karstification. Synthèse spéléologique et karstique, Les facteurs géo-graphiques, 3, Spéléo-Club de Paris, Club Alpin Français, Paris, 69 p.

Cocean, P., 1975. Sur la genese de la voute planehorizontale de la grotte „Pestera cu Apă din Valea Lesului“. Travaux de L' Institute de Spéologie „Émile Racovitza“, 14, 189-196.

Cocean, P., 1979. Les voutes planes-horizontales et le niveau de base karstique. Travaux de L' Institute de Spéologie „Émile Racovitza“, 18, 219-224.

Cohen, K.M., Gibbard, P.L., 2019. Global chronostratigraphical correlation table for the last 2.7 million years, version 2019 QI-500. Quaternary International, 500, 20-31. https://doi.org/10.1016/j.quaint.2019.03.009

Curl, R.L., 1966. Cave conduit enlargement by natural convection. Cave Notes, 8(1), 2-6.

Droppa, A., 1957. Ochtinská aragonitová jaskyňa. Geografický časopis, 9(3), 169-184.

Fisher, R., 1953. Dispersion on a sphere. Proceedings of the Royal Society, A 217, 295-305.

https://doi.org/10.1098/rspa.1953.0064

Ford, D.C., Williams, P.W., 2007. Karst hydrogeology and geomorphology. Wiley, Chichester, $562 \mathrm{p}$. https://doi.org/10.1002/9781118684986

Fusán, O., 1957. Paleozoikum gemeríd. Geologické práce, Zošit 46, 17-36.

Gaál, L., 1996. Prieskum a ochrana aragonitových jaskýn̆ v okolí Hrádku. In: Bella, P. (Ed.), Sprístupnené jaskyne - výskum, ochrana a využivanie. Zborník referátov $z$ odborného seminára (Medzev 18. - 20. 9. 1996). SSJ, Liptovský Mikuláš, p. 130-133.

Gaál, L., 2004. Geológia Ochtinskej aragonitovej jaskyne. Slovenský kras, 42, 37-56.

Gaál, L., Ženiš, P., 1986. Kras Revúckej vrchoviny. Slovenský kras, 24, 27-60.

Gechter, D., Huggenberger, P., Ackerer, P., Waber, H.N., 2008. Genesis and shape of natural solution cavities within salt deposits. Water Resources Research, 44, W1 1409. https://doi.org/10.1029/2007WR006753

Goodman, L.R., 1964. Planes of repose in Höllern, Germany. Cave Notes, 6(3), 17-19.

Grecula, P., 1982. Gemerikum - segment riftogénneho bazénu Paleotetýdy. Mineralia Slovaca, Monografia, II, Alfa, Bratislava, 263 p.

Grecula, P. (Ed.), Kobulský, J., Gazdačko, L., Németh, Z., Hraško, L., Novotný, L., Maglay J., 2009. Geological map of the Spiš-Gemer Ore Mountains 1:50.000. State Geological Institute of Dionýz Štúr, Bratislava.

Gripp, K., 1913. Über den Gipsberg in Segeberg und die in ihm vorhandene Höhle. Jahrbuch der Hamburgischen Wissenschaftlichen Anstalte, 30/1912(6) [Mitteilungen aus dem Mineralogisch-Geologischen Institut in Hamburg, 2], 35-51.

Haviarová, D., Peško, M., 2004. Základná charakteristika vôd Ochtinskej aragonitovej jaskyne. Slovenský kras, 42, 99-107.

Hellstrom, J., 2003. Rapid and accurate U/Th dating using parallel ion-counting multicollector ICP-MS. Journal of Analytical Atomic Spectrometry, 18(11), 1346-1351. https://doi.org/10.1039/b308781f

Hellstrom, J., 2006. U-Th dating of speleothems with high initial 230Th using stratigraphical constraint. Quaternary Geochronology 1(4), 289-295. https://doi.org/10.1016/j.quageo.2007.01.004

Hill, C.A., Forti, P. 1995. The classification of cave minerals and speleothems. International Journal of Speleology, 24(1-4),77-82.

Holden, N.E., 1990. Total half-lives for selected nuclides.
Pure and Applied Chemistry, 62(5), 941-958.

https://doi.org/10.1351/pac199062050941

Homza, Š., Rajman, L., Roda, Š., 1970. Vznik a vývoj krasového fenoménu Ochtinskej aragonitovej jaskyne. Slovenský kras, 8, 21-68.

Hurai, V., Harčová, E., Huraiová, M., Ozdín, D., Prochaska, W., Wiegerová, V., 2002. Origin of siderite veins in the Western Carpathians I. P-T-X- $\delta^{13}-\mathrm{C}-$ $\delta^{18} \mathrm{O}$ relations in ore-forming brines of the Rudnany deposits. Ore Geology Reviews, 21, 67-101.

https://doi.org/10.1016/S0169-1368(02)00082-3

Ivanovich, M., Harmon, R.S., 1982. Uranium Series Disequilibrium. Applications to Environmental Problems. Clarendon Press, Oxford, 571 p.

Jaffey, A.H., Flynn, K.F., Glendenin, L.E., Bentley, W.C., Essling, A.M., 1971. Precision Measurement of HalfLives and Specific Activities of ${ }^{235} \mathrm{U}$ and ${ }^{238} \mathrm{U}$. Physical Reviews C, 4(5), 1889-1906.

https://doi.org/10.1103/PhysRevC.4.1889

Kempe, S., 1970. Beiträge zum Problem der Speläogenese im Gips unter besonderer Berücksichtigung der Unterwasserphase. Die Höhle, 21(3), 126-134.

Kempe, S., 1972. Cave genesis in gypsum with particular reference to underwater conditions. Cave Science, 49, $1-6$.

Kempe, S., 1975. Siderite weathering, a non-biogenetic source of $\mathrm{CO}_{2}$ (illlustrated by the Iberg/Harz/Fed. Rep. of Germany). Annales de Spéléologie, 30(4), 703-704. https://doi.org/10.3406/ahess.1975.293641

Kempe, S., 1996a. Gypsum karst of Germany. International Journal of Speleology, 25(3-4), 209-224. https://doi.org/10.5038/1827-806X.25.3.16

Kempe, S., 1996b. Steter Tropfen hohlt den Stein? Wie Hohlen wirklich entstehen. In: Rosendahl, W., Krause, E.-B. (Eds.), Im Reich der Dunkelheit: Höhlen und Höhlenforschung in Deutschland. Edition Archaea, Gelsenkirchen, p. 22-32.

Kempe, S., 1998. Siderite weathering, a rare source of $\mathrm{CO}_{2}$ for cave genesis: the Eisenstein Stollen System and adjacent caves in the Iberg, Harz Mountains, Germany. Journal of Cave and Karst Studies, 60(3), 188. https://caves.org/pub/journal/PDF/V60/V60N3Abstracts.pdf

Kempe, S., 2009. Siderite weathering as a reaction causing hypogene speleogenesis: The example of the Iberg/Harz/Germany. In: Klimchouk, A.B., Ford, D.C. (Eds.), Hypogene Speleogenesis and Karst Hydrogeology of Artesian Basins. Ukrainian Institute of Speleology and Karstology, Simferopol, Special Paper, 1, p. 59-60.

Kempe, S., Bauer, I., Krause, O., 2016. Iberger Tropfsteinhöhle, Iberg, Harz Mountains, Germany: Hypogene morphology and origin by siderite weathering. In: Chavez, T., Reehling, P. (Eds.), Proceedings of DeepKarst 2016: Origins, Resources, and Management of Hypogene Karst (April $11-14$, 2016, Carlsbad, New Mexico). NCKRI Symposium, 6, National Cave and Karst Research Institute, Carlsbad, New Mexico, p. 35-44.

Kempe, S., Brandt, A., Seeger, M., Vladi, F., 1975. "Facetten" and "Laugdecken", the typical morphological elements of caves developed in standing water. Annales des Spéléologie, 30(4), 705-708.

Kirschvink, J.L., 1980. The least-squares line and plane and the analysis of palaeomagnetic data. Geophysical Journal International, 62(3), 699-718.

http://dx.doi.org/10.1111/j.1365-246X.1980. tb02601.x

Korpel, P., Kotras, J., 1957. Záverečná zpráva a výpočet zásob z ložiska Hrádok - ankerit, oker (so stavom 31. 
12. 1954). I. a II. čast'. Archive ŠGÚDŠ, Spišská Nová Ves, $554 \mathrm{p}$.

Krs, M., Pruner, P. 1999. Comparative paleomagnetic, paleotectonic and paleogeographical investigations in the Alpine and Variscsan tectonic belts: case histories from the Western Carpathians and the Bohemian Massif. Geologica Carpathica, 50, special issue, 44-48.

Kubiny, D., 1959. Aragonitová jaskyňa na Slovensku. Ochrana přirody, 14(1), 17-18.

Lange, A.L., 1962. Water level planes in caves. Cave Notes, 4(2), 12-16.

Lange, A.L., 1963. Planes of repose in caves. Cave Notes, 5(6), 41-48.

Lange, A.L. 1968. The changing geometry of cave structures. Part III: Summary of solution processes. Caves and Karst, 10(3), 29-32.

Márton, E., Grabowski, J., Plašienka, D., Túnyi, I., Krobicki, M., Haas, J., Pethe, M. 2013. New paleomagnetic results from the Upper Cretaceous red marls of the Pieniny Klippen Belt, Western Carpathians: evidence for general $\mathrm{CCW}$ rotation and implications for the origin of the structural arc formation. Tectonophysics, 592, 1-13. https://doi.org/10.1016/j.tecto.2013.01.027

Mišik, M., 1953. Geologické pomery územia medzi Jelšavou a Štítnikom. Geologický sborník, 4(3-4), 557-587.

Nicod, J., 1976. Les régions karstiques de Slovaquie et de Hongrie septentrionale. Bulletin de la Société géographique de Marseille 82, nouvelle série 12, 11-25.

Palmer, A.N., 1991. Origin and morphology of limestone caves. Geological Society of America Bulletin, 103 (1), 1-21. https://doi.org/10.1130/00167606(1991)103<0001:OAMOLC $>2.3 . \mathrm{CO} ; 2$

Palmer, A.N., 2007. Cave geology. Cave Books, Dayton, 454 p.

Palmer, A.N., 2011. Distinction between epigenic and hypogenic maze caves. Geomorphology, 134 (1), 9-22. https://doi.org/10.1016/j.geomorph.2011.03.014

Parkhurst, D.L., Appelo, C.A.J., 1999. PHREEQC-2, a hydrogeochemical computer program. U.S. Geological Survey Water Resources Investigation Report 99-4259, 312 p.

Peško, M., 2002. Fyzikálno-chemické vlastnosti priesakových vôd v Ochtinskej aragonitovej jaskyni. In: Bella, P. (Ed.), Výskum, využivanie a ochrana jaskýn̆. Zborník referátov $z$ 3. vedeckej konferencie (Stará Lesná 14-16. 11. 2001). SSJ, Liptovský Mikuláš, p. 108-111.

Potočný, T., Méres, Š., Plašienka, D., 2020. Geological structure and tectonometamorphic evolution of the Veporic-Gemeric contact zone constrained by the monazite age data (Slavošovce - Štítnik area, Western Carpathians, Slovakia). Mineralia Slovaca, 52(2), 83-102.
Pruner, P., Bosák, P., Kadlec, J., Venhodová, D., Bella, P., 2000. Paleomagnetický výzkum sedimentárních výplní vybraných jeskyní na Slovensku. In: Bella, P. (Ed.), Výskum, využivanie a ochrana jaskýň. Zborník referátov z 2. vedeckej konferencie (Demänovská Dolina 16-19. 11. 1999). SSJ, Liptovský Mikuláš, p. 13-25.

Přihoda, K., Krs, M., Pešina, B., Bláha, J., 1989. MAVACS - a new system creating a nonmagnetic environment for palaeomagnetic studies. Cuadernos de Geologica Ibérica, 12, 223-250.

Pukanská, K., Bartoš, K., Bella, P., Gašinec, J., Blistan, P., Kovanič, L., 2020. Surveying and high-resolution topography of the Ochtina Aragonite Cave based on TLS and digital photogrammetry. Applied Sciences, 10(13), 4633. https:/ / doi.org/10.3390/app10134633

Rajman, L., Roda, Š., Roda, Š. jr., Ščuka J., 1990. Fyzikálno-chemický výskum krasového fenoménu Ochtinskej aragonitovej jaskyne. Final report (manuscript), SMOPaJ, Liptovský Mikuláš.

Rajman, L., Roda, Š. jr., Roda, Š. sen., Ščuka, J., 1993. Unterchungen (ber die Genese der Aragonithöhle von Ochtiná (Slowakei). Die Höhle, 44(1), 1-8.

Reinboth, F., 1968. Beiträge zur Theorie der Gipshöhlenbildung, Die Höhle, 19(3), 75-83.

Reinboth, F., 1971. Zum Problem der Facetten- und Laugdeckenbildung in Gipshöhlen. Die Höhle, 22(3), 88-92.

Reinboth, F., 1992. Laborversuche zur Entstehung von Stillwasserfacetten und Laugdecken - mit einem kritischen Überblick zum Stand der Diskussion. Die Höhle, 43(1), 1-18.

Sassi, F.P., Vozárová, A., 1987. The pressure character of the Hercynian metamorphism in the Gemericum (West Carpathians, Czechoslovakia). Rendiconti della Società Italiana di Mineralogia e Petrologia, 42(1), 73-81.

Ščuka, J., Roda, Š. jr., Rajman, L., Roda, Š. sen., 1988. Problemy genezisa karstovogo fenomena Ochtinskoj aragonitovoj peščery. In: Communications, International Symposium on Physical, Chemical and Hydrological Research of Karst, Košice, p. 181-185.

Ševčik, R., Kantor, J., 1956. Aragonitová jaskyňa na Hrádku pri Jelšave. Geologické práce, Správy, 7, 161-171.

Vozárová, A., Vozár, J., 1988. Late Paleozoic in West Carpathians. GÚDŠ, Bratislava, 314 p.

Webb, J. A., 2020. Supergene sulfuric acid speleogenesis and the origin of hypogene caves: evidence from the Northern Pennines, UK. Earth Surface Processes and Landforms, 46(2), 455-464. https://doi.org/10.1002/esp.5037

Zupan Hajna, N., Mihevc, A., Pruner, P., Bosák, P., 2008. Palaeomagnetism and magnetostratigraphy of karst sediments in Slovenia. Carsologica, 8, Založba ZRC SAZU, Postojna, 266 p. 